\title{
Sustainable chemical processing and energy-carbon dioxide management: review of challenges and opportunities
}

Frauzem, Rebecca; Vooradi, Ramsagar ; Bertran, Maria-Ona; Frauzem, Rebecca; Anne, Sarath Babu; Gani, Rafiqul

Published in:

Chemical Engineering Research \& Design

Link to article, DOI:

10.1016/j.cherd.2017.12.019

Publication date:

2018

Document Version

Early version, also known as pre-print

Link back to DTU Orbit

Citation (APA):

Frauzem, R., Vooradi, R., Bertran, M-O., Frauzem, R., Anne, S. B., \& Gani, R. (2018). Sustainable chemical processing and energy-carbon dioxide management: review of challenges and opportunities. Chemical

Engineering Research \& Design, 440-464. https://doi.org/10.1016/j.cherd.2017.12.019

\section{General rights}

Copyright and moral rights for the publications made accessible in the public portal are retained by the authors and/or other copyright owners and it is a condition of accessing publications that users recognise and abide by the legal requirements associated with these rights.

- Users may download and print one copy of any publication from the public portal for the purpose of private study or research.

- You may not further distribute the material or use it for any profit-making activity or commercial gain

- You may freely distribute the URL identifying the publication in the public portal 


\title{
Sustainable chemical processing and energy-carbon dioxide management: review of challenges and opportunities
}

Ramsagar Vooradi ${ }^{2}$, Maria-Ona Bertran ${ }^{1}$, Rebecca Frauzem ${ }^{1}$, Sarath Babu Anne ${ }^{2}$, Rafiqul Gani ${ }^{1}$

${ }^{1}$ Department of Chemical \& Biochemical Engineering, Technical University of Denmark, DK2800 Lyngby, Denmark

${ }^{2}$ Chemical Engineering Department, National Institute of Technology Warangal, Telangana506004, India

\begin{abstract}
This paper presents a brief review of the available energy sources for consumption, their effects in terms of $\mathrm{CO}_{2}$-emission and its management, and sustainable chemical processing where energy-consumption, $\mathrm{CO}_{2}$-emission, as well as economics and environmental impacts are considered. Not all available energy sources are being utilized efficiently, while, the energy source causing the largest emission of $\mathrm{CO}_{2}$ is being used in the largest amount. The $\mathrm{CO}_{2}$ management is therefore looking at "curing" the problem rather than "preventing" it. Examples highlighting the synthesis, design and analysis of sustainable chemical processing in the utilization of biomass-based energy-chemicals production, carbon-capture and utilization with zero or negative $\mathrm{CO}_{2}$-emission to produce value added chemicals as well as retrofit design of energy intensive chemical processes with significant reduction of energy-consumption are presented. These examples highlight issues of energy-sustainable design, energy- $\mathrm{CO}_{2}$ neutral design, energy-retrofit design, and energy-process intensification. Finally, some perspectives on the status and future directions of carbon dioxide management are given.
\end{abstract}

\section{Keywords}

Carbon dioxide management; Energy efficiency; Process synthesis; Sustainable process design Process intensification; Process Systems Engineering

\section{Introduction}

Energy consumption per capita is one of the most important parameters to assess the quality of life of the population of a country. Thus, sustainable harnessing of the available energy resources with a view to meet the necessities of increasing world population, to ensure a safe and healthy living of the present as well as the future generations on earth, is an essential ingredient of all governmental planning (Brundtland Commission, 1987). As Figure 1 shows, the total world energy consumption is reported to rise to 815 quadrillion Btu in 2040 from 549 quadrillion Btu in 2012, that is, an increase of $48 \%$ in a span of 28 years (The International Energy Outlook, 2016). As can be seen from Figure 1, fossil fuels are going to be the mainstay for global energy requirements, for several decades to come. However, if adequate measures are not employed, the use of fossil fuels for power generation is bound to result in increased $\mathrm{CO}_{2}$ releases. 
Additionally, use of fossil fuels for transportation, industrial operations and agricultural activities are associated with massive global $\mathrm{CO}_{2}$ emissions and the resultant increase in the atmospheric $\mathrm{CO}_{2}$ levels. It is established that carbon dioxide alone accounts for nearly (77\%) of the global Green House Gas (GHG) emissions (IPCC, 2007). Recently, in view of generation of energy from renewable sources (solar energy, wind energy, tidal energy, etc.) as well as the need for more efficient usage of energy, supplementing, and/or replacing non-renewable sources (coal, crude-oil, natural gas, etc.) as well as reducing their usage has become an alternative worth investigating. The availability of these resources is however, dependent on geographic location as well as the seasonal and nocturnal variations. Furthermore, the requirement of land for exploitation of solar and wind is considerably high.

[Insert Figure 1 here]

A target level of $450 \mathrm{ppm} \mathrm{CO}_{2}$-equivalent concentration has been predicted by many models as the concentration needed to stabilize the global average temperature increase to $2{ }^{0} \mathrm{C}$ at the end of 21st century (Hare, et al. 2011; OECD, 2012). Global $\mathrm{CO}_{2}$ monitoring at Mauna Loa in Hawaii shows that the concentration of $\mathrm{CO}_{2}$ is already above $400 \mathrm{ppm}\left(\mathrm{CO}_{2}\right.$-Earth, 2017), that is, almost nearing the established target limit. To limit the $\mathrm{CO}_{2}$-equivalent concentration to $450 \mathrm{ppm}$, between $40 \%$ to $70 \%$ of the total anthropogenic emissions need to be reduced by 2050 , compared to 2010 emissions, and no anthropogenic emissions by 2100 (IPCC, 2014). Hence the present practice of using fossil fuels as the energy source must not continue and there is an urgent need to reduce the $\mathrm{CO}_{2}$ emission and thereby, global warming through better management of energy-consumption, $\mathrm{CO}_{2}$-emission and their management. To reduce the global carbon dioxide emissions, different approaches have been proposed:

- improvement of process efficiencies to reduce energy consumption (Duflou, et al. 2012; Tula, et al. 2017);

- utilization of alternative energy sources (e.g., solar energy, wind power and geothermal) and renewable (e.g., biomass and biofuel) as opposed to currently dominant fossil fuel based sources (Karakosta, et al. 2013; Hussain, et al. 2017);

- application of carbon dioxide capture, sequestration \& utilization (CCS \& U) technologies (Cuellar-Franca and Azapagic, 2015; Dowell, et al. 2017).

For a sustainable energy management scenario, not just one of the above approaches, but a judicious mix of all three needs to be employed. However, such an integrated approach would need to address issues of economic feasibility, energy consumption and related direct-indirect $\mathrm{CO}_{2}$ emissions together with other performance factors. Therefore, the availability of energy sources, the $\mathrm{CO}_{2}$-emission and management and sustainability of manufacturing process alternatives need to be carefully studied to determine the best options.

Due to the increasing emissions from industrial sources, natural removal of GHG via photosynthesis and absorption on the sea surface are not able to balance the emission sources and therefore cannot keep the $\mathrm{CO}_{2}$ concentration within the desired threshold limit of $450 \mathrm{ppm}$ (Peters, et al. 2012). The scope of some recent techno-economic studies (Rubin, et al. 2012; 
Yuan, et al. 2016; and Rahman, et al. 2017) on combined $\mathrm{CO}_{2}$ capture and sequestration (CCS), and $\mathrm{CO}_{2}$ capture and utilization (CCU) are highlighted in Figure 2. Frauzem et al (2017) have reported results from sustainable design of $\mathrm{CCU}$ for the production of higher value chemicals like dimethyl carbonate.

[Insert Figure 2 here]

Although CCS and CCU have the potential to significantly impact the stabilization of $\mathrm{CO}_{2}$ concentration in the atmosphere, in their execution, challenges such as additional cost, storage related problems, technical competences, organizational policies and environmental complexities have not yet been adequately addressed (Rahman, et al. 2017). The enormity of the energy management- $\mathrm{CO}_{2}$ mitigation problem raises the question - would the current $\mathrm{CCS}$ and $\mathrm{CCU}$ efforts actually reduce the global warming (or $\mathrm{CO}_{2}$ concentration in the atmosphere) to the desired level? The current global emission rate of $\mathrm{CO}_{2}$ is about $35.5 \mathrm{Gt}$ per year due to various anthropogenic activities, requiring a volume of 1,033 million barrels per day of emitted $\mathrm{CO}_{2}$ at a possible storage condition of pressure $=10 \mathrm{MPa}$, temperature $=40{ }^{0} \mathrm{C}$ and density $=600 \mathrm{~kg} / \mathrm{m}^{3}$. This volume is approximately 10 times greater than the current global oil production. Presently more than 60 million tons per year of $\mathrm{CO}_{2}$ is used for enhanced oil recovery (EOR) application and a similar amount is captured and sequestered (Wallace and Kuuskraa, 2014; Dowell, et al., 2017). In 2013, $200 \mathrm{Mt}$ of $\mathrm{CO}_{2}$ was utilized to yield different products and in 2016 the forecasted $\mathrm{CO}_{2}$ utilization is about $299 \mathrm{Mt}$. In order to stabilize the global $\mathrm{CO}_{2}$ concentration at $450 \mathrm{ppm}$, it is expected that about 120-160 Gt of $\mathrm{CO}_{2}$ will need to be sequestered by 2050 (IEA, 2013). The analysis by Dowell, et al., 2017 shows that about $800 \mathrm{Gt}$ of $\mathrm{CO}_{2}$ need to be captured during the 2010-2150 period in order to ensure that global temperature rise will not exceed by $2{ }^{0} \mathrm{C}$. In order to meet the mitigation challenge of $800 \mathrm{Gt}$ of $\mathrm{CO}_{2}$ in a sustainable manner, recent technologies, such as the use of $\mathrm{CO}_{2}$ in enhanced oil recovery $\left(\mathrm{CO}_{2}\right.$-EOR) and carbon capture and utilization (CCU), will need to be well established to take equal share along with carbon capture and sequestration (CCS), which could be considered as a mature technology compared with the other two.

As can be observed from the above discussion, much of the effort put on reducing the $\mathrm{CO}_{2}$ concentration levels in the atmosphere appears to be trying to "cure" the problem rather than "preventing" the problem. That is, curing the problem is to capture the $\mathrm{CO}_{2}$ after it has been generated and released mostly because of the use of fossil fuel based energy. Preventing the problem, on the other hand, is generating and releasing significantly lower amounts of $\mathrm{CO}_{2}$, by for example, reducing the consumption of fossil fuel through improved process design-synthesisintensification.

Sustainability is defined as "the ability to meet current needs without compromising the ability of future generations to meet their needs" (Brundtland Commission, 1987). The past environmental issues, including global warming, prompted the Brundtland Commission to recommend the search for sustainable solutions. In this respect, sustainable chemical and biochemical processes must perform better than existing process alternatives measured in terms of a set of sustainability 
(performance) metrics (IChemE, 2002). Among the sustainability metrics, the need for energy per kg product, the carbon foot-print, the global warming potential, among others are included, as well as economic-social factors such as profit and jobs created. Therefore, finding more sustainable process alternatives means, for example, more profit, less energy consumption and lower carbon foot-print.

The objective of this paper is to briefly review the current state of the art in availabilityutilization of different energy sources, the consequent $\mathrm{CO}_{2}$-emission management as well as developments in sustainable chemical process synthesis-design. In section 2, a brief review on the utilization of fossil fuels and other energy sources, including renewable sources are presented along with the associated challenges with respect to production costs and associated $\mathrm{CO}_{2-}$ emissions. Also, perspectives on replacing the fossil fuels with renewable and green sources are discussed. In section 3, issues related to $\mathrm{CO}_{2}$ emission and management, including capture, sequestration and conversion are highlighted together with perspectives on their efficient management. Section 4 highlights developments in sustainable chemical process synthesisdesign in terms of economics, energy conservation, safety, environmental, and social impacts. Section 5 presents examples of application of a 3-stage method for sustainable chemical process design for biorefinery, net $\mathrm{CO} 2$ negative sustainable designs of $\mathrm{CO} 2$ capture and utilization processes for production of value-added chemicals as well as applications of hybrid and process intensification methods to retrofit design with significant reduction of energy consumption.

\section{Available Energy Sources}

Energy is defined as capacity to do work and it manifests itself in many forms. Planet earth contains different forms of energy sources such as fossil fuels, renewables (biomass), nuclear and green energy sources (such as solar, wind, geothermal and hydro) from which high grade thermal energy can be obtained. This section briefly reviews the different energy sources, their usage statistics and associated environmental and technical challenges.

\subsection{Energy from fossil fuels}

Since the industrial revolution, fossil fuels such as coal, gas and oil have been considered to be the main energy sources to meet the ever increasing energy demand (Huber, 2009). Because of their ease of use, availability and price, compared to other energy sources, fossil fuels are currently the dominant energy source. In general, the use of fossil-based energy had a positive impact on economic growth and at the same time it had a negative impact on environment due to GHG emissions. One way to control these emissions is to implement energy-electricity conservation policies. However, the impact of such conservation policies on economic growth can be negative or positive depending on specific locations (Sharma, 2010). Also, this introduces a "social" dimension to the problem, which though very important, is outside the scope of this article.

Figure 3 shows $\mathrm{CO}_{2}$ emission from the use of fossil fuels. Because of their abundance and relatively lower costs, fossil fuels are used widely in domestic as well as transport sectors in 
addition to major applications in various industrial sectors. Figure 3(a) shows the emissions from use of fossil fuels in all sectors while Figure 3(b) shows only those from industrial sectors. As can be seen from the Fig 3(b), electric power plants are mainly responsible for the atmospheric $\mathrm{CO}_{2}$ emissions, with a share of about $50 \%$. In view of the unavoidable dependence on fossil fuels, at least for several decades, for meeting the global energy demand along with effective CCS or CCU techniques are essential to contain the $\mathrm{CO}_{2}$ emissions. This, however, is "curing" the problem after it has occurred. According to IPCC report on Climate Change 2014, in order to maintain $\mathrm{CO}_{2}$ concentration at $450 \mathrm{ppm}$ by $2100, \mathrm{CO}_{2}$ emissions from the energy supply sector are expected to decline significantly over the next decade and in between 2040 and 2070 the emissions are supposed to reduce by $90 \%$ or more below 2010 levels. The "curing" strategies alone cannot handle this task efficiently due to the large volume of $\mathrm{CO}_{2}$ that need to be captured and sequestrated or utilized. Green energy technologies (solar, hydro, wind) along with energy efficient industrial processes can substantially reduce the burden on curing strategies by minimizing emissions. That is, to "prevent" the problem, it is necessary to implement energy efficient process designs and green energy technologies that significantly reduce the process energy demand and GHG emissions.

[Insert Figures 3a-3b here]

\subsection{Renewable \& green energy sources}

Renewable energy is the energy obtained from renewable resources, which naturally restore on earth and/or in atmosphere on a human timescale. The main stream of renewable resources is biomass. Energy from renewables is a potential alternative to fossil fuel energy. In 2015, 1823 million tons of oil equivalents (Mtoe) of world Total Primary Energy Supply (TPEC) was from renewable and green energy sources (see Figure 4a). Renewable and green energy sources produce $22.8 \%$ of the total world electricity, which is the third largest contributor to global electricity production in 2015 (see Figure 4b). In this sub-section, the current state of art related to some of the important emerging renewable and green energy sources is discussed. Finally this sub-section is concluded with, some research facts on "do alternative energy sources displace fossil fuels?"

[Insert Figures $4 \mathrm{a}$ and $4 \mathrm{~b}$ here]

Bioenergy: Energy in the form of heat/electricity/transportation fuel, which is derived from the any biomass is referred to as Bioenergy (Creutzig, et al. 2014). Currently bioenergy accounts for about $10 \%$ of global primary energy supply (Anselm and Adam, 2014). Currently $90 \%$ of the total domestic heating requirement and $7 \%$ of the industrial heat requirement are by biomass (REN21, 2017). In the year 2012, about 1900 barrels per day bio fuel and approximately 400 trillion kilowatt hours of electricity is produced from biomass (Faik, et al. 2017). In 2016, 4\% of the world's transport fuel demand is supplemented using biofuels. Recently, bioenergy attracted much attention due to the following advantages: substantial sources (Teske, et al. 2011), techno economic feasibility (Bhattacharya, et al. 2003), ensuring national energy security (Van Loo and Koppejan, 2008), enhancing rural employment and agricultural economy (Demirbas, et al. 2009), low $\mathrm{CO}_{2}$ emissions (Faik, et al. 2017). However, the use of biomass on a large scale may not be a 
sustainable option due to the following challenges: Natural vegetation has to be sacrificed for crop-based biofuels to accommodate their increase in demand (Elshout, et al. 2015), deforestation due to massive production of bioenergy (Rajcaniova, et al. 2014).

Solar energy: Solar energy is a primary source of energy that is abundantly available in most parts of the world. Sun emits solar energy at the rate of $3.8 \times 10^{23} \mathrm{KW}$, of which only $1.8 \times 10^{14}$ $\mathrm{KW}$ is intercepted by earth (Panwar, et al. 2011). There is sufficient scope to utilize available solar energy via solar thermal and solar photovoltaic (PV) based systems. In spite of several advantages, such as abundance, low contribution to carbon footprints, major barriers for solar energy are its fluctuating nature and high cost technology (Devabhaktuni, et al. 2013, Mohanty, et al. 2017). Many researchers investigated global solar energy scenarios, developments in solar power generation, photovoltaic collectors, solar heaters, design improvements and sizing, materials for efficient light absorption to overcome barriers and upgrade solar industry as a potential application (Kannan and Vakeesan, 2016; Modi, et al. 2017; Devbhaktuni, 2013; Mekhilef, et al. 2011). Figure 5 highlights the global capacity of solar photovoltaic (PV), Concentrating Solar Power (CSP) energy production and solar water heating applications, for the year 2015-2016 (REN21, 2017). Significant increase of total capacity generation in solar thermal energy applications represent the incorporation of new technologies and design improvements.

[Insert Figure 5 here]

Wind energy: Much like solar energy, wind energy also comprises only a small amount of the total energy that reaches the earth surface. It can be used either directly as mechanical power or indirectly by converting the kinetic energy of wind into electrical energy by means of wind turbine. In this technology, wind turbine is sub-divided into two categories, onshore wind turbines and offshore wind turbines. Both these turbine technologies bear striking similarities, the only significant difference being the design of the offshore wind turbines that require floating or other special foundations to account for underwater tower submergence (Kumar, 2016). Some of the main advantages of wind energy are its easy accessibility, pollution free energy source and feasibility for installation in rural areas. Wind energy also preserves the land and environment in rural areas and agriculture and animal husbandry in the vicinity can be easily dealt with. Although there are many advantages of wind energy, some of its main disadvantages are its unreliability, due to varying wind speed and noise pollution in the vicinity (Kaplan, 2015).

Figure 6 shows the installed wind power capacity in the world from 2001 to 2016. It is seen from Fig 6 that the world's total installed capacity was $486.749 \mathrm{GW}$ with more than $12 \%$ growth rate in the annual market at the end of 2016.The steady increase of global wind energy generation capacity clearly indicates that there is a very large and growing global demand for emissions-free wind power almost throughout the world (GWEC, 2017). The wind industry sector also creates many new jobs, nearly half a million people are employed in this industry, and this number is expected to increase further (GWEC, 2012).

[Insert Figure 6 here]

Geothermal energy: The thermal energy available on earth's crust is called geothermal energy and energy is released due to radioactive decay of minerals including potassium, uranium and 
thorium (Bahadori, et al. 2013). In the year 2016, 157 TWh of geothermal energy is produced in the form of electricity and thermal output (REN21, 2017). The main competing advantages of geothermal energy are low carbon emissions in energy production compared to fossil fuels and power production not being intermittent in nature, unlike solar and wind power (Abbas et al. 2014). Indonesia and Turkey installed the highest capacity (205 MW and 197 MW respectively) geothermal power plants in the year 2016 (REN21, 2017). To produce geothermal energy in a sustainable manner, research should be focused on addressing the issues highlighted in Figure 7 (Jiang, et al. 2017; Shortall, et al. 2015; Fridleifsson, et al. 2001; Chen and Jiang 2015; Kagel, et al. 2007).

[Insert Figure 7 here]

Hydro energy: Hydropower is a clean, efficient and hassle-free technology of power generation, as compared to other renewable energy sources. The flexibility and storage capacity of hydropower not only makes it possible to improve grid stability but also support the deployment of other intermittent renewable energy sources such as wind and solar power. Among all renewable energy sources, plant life of hydro power is the highest, about 35 years and generation tariff is the lowest, between 63.33-87.50 USD/MWh (Mishra et al., 2015). These advantages make it one of the best options as a renewable and sustainable energy source. Hydropower plants are categorized as reservoir based and run of river type. The run of river scheme harnesses energy from flow of water to produce power. Consequently, it has a low environmental impact and does not necessitate rehabilitation of people. Hydropower currently contributes to more than $50 \%$ of electricity derived from green energy sources (see Figure 4). Despite these advantages, large hydro projects face continued opposition due to their environmental and social repercussions (landscape, biodiversity, wildlife, population settlement, health, and water quality). The percentage of undeveloped hydropower capacity is very high in certain regions: Africa (92\%), followed by Asia (80\%), Oceania (80\%) and Latin America (74\%) (Ardizzon, 2014). With small size projects and improved designs for minimizing the environmental effects, hydropower production can be a viable option.

Tidal energy: Around 70\% of the earth's mass is covered by oceans, which are a great green energy source. Energy is stored in oceans in the form of thermal energy (heat), kinetic energy (tides and waves), chemical energy (chemicals) and biological energy (biomass). Uninterrupted supply of tidal energy due to dynamic behavior of the oceans makes it a reliable energy source (Khan, 2017). As it depends only on the gravitational attraction between the moon and the sun and the centrifugal forces due to the rotation of the earth and moon, it is predictable in nature (Rourke, 2010). Among the ocean energy technologies, wave and ocean thermal technologies are at an early stage of development (Uihlein, 2016). Small to medium capacity tidal power generation plants (3.2-250 MW) are under operation globally and big capacity projects (2000$1200 \mathrm{MW}$ ) are being planned (Khan, 2017). Segura, (2017) carried out life-cycle cost assessment of different energy systems and presented in terms of levelized cost of energy (LCOE), showing that LCOE is very high for wave and tidal, due to premature technologies. 


\subsection{Nuclear energy}

Nuclear energy is the only base load power source that can replace/supplement fossil fuels. During 2014 about 10\% of total world energy consumption has been met from nuclear energy and in 2016, total nuclear capacity supplying electricity to the grid is $350 \mathrm{GWe}$ (WNN, 2017). The International Energy Outlook 2016 reports that nuclear power generation is expected to increase from 2.3 trillion $\mathrm{kWh}$ in 2012 to 3.1 trillion $\mathrm{kWh}$ in 2020 and to 4.5 trillion $\mathrm{kWh}$ in 2040. The main advantages of nuclear energy are high capacity factor, low $\mathrm{CO}_{2}$ emissions and relatively small amount of fuel required (the energy of $1 \mathrm{~kg}$ of Uranium is equivalent to 2.7 million kg coal). Presently, all nuclear reactors producing energy are based on nuclear fission reaction and various types of reactors and fuel cycles are developed. The amount of vitrified High Level Waste generated from the nuclear fission plants is very small and can be safely managed. In-spite of the above advantages, the nuclear power production by fission is still associated with the following challenges: Management of very hazardous radioactive wastes, including final disposal, non-ecofriendly production of nuclear fuel, radiation released during accidents and low thermal efficiency in case of electric power production. However, improvements in the thermal efficiency, safety and waste management practices, will favor nuclear energy usage towards the sustainable development (Pioro and Duffey, 2015). Research on nuclear fusion is in advanced stages in different countries. In November 2006, seven countries, China, India, Japan, Russia, South Korea, the USA and the European Union, signed an agreement for construction and operation of a $500 \mathrm{MW}$ an International Thermonuclear Experimental Reactor (ITER) and work is under progress (NPE, 2017). As fusion reactors do not generate long-lived High Level Waste and are safer to operate, when this technology matures, it could be a very effective replacement for fossil fuels.

\subsection{Perspectives on replacement of fossil fuels with alternative energy sources}

Extensive studies establishing a link between energy and growth have been reported (Ozturk, 2010; Omri, 2014). In order to make the growth sustainable and inclusive, recent studies have mainly focused on establishing the link between energy, emission and growth (Adeolu \& Olabanji, 2017). Life cycle analysis performed (Amponsah, 2014) to assess the total burden of $\mathrm{CO}_{2}$ emission on environment by including all the stages of energy production processes such as upstream stage: resource extraction, plant construction, material and component manufacturing; operation stage (combustion, plant maintenance and operation); downstream stage (dismantling, decommissioning, disposal and recycling) not surprisingly point to energy production from fossil fuels has high life cycle emissions compared to renewable, green and nuclear sources.

The extraction of energy from renewable, green and nuclear sources is a promising option to minimize the use of energy from fossil fuels, which could be used mainly for transportation and value added chemical productions. During the period 2012 to 2040, renewable and green sources are projected to be fastest-growing energy source with an increase in consumption by 2.6 percent per year and nuclear increasing by 2.3 percent per year. Currently research is focused on enhancing the energy extraction efficiency from renewable and green sources. However, with the 
present growth rate and capacity (see Table 1), the renewable and green energy sources cannot completely replace the fossil fuels, to meet the global base load energy demand, in foreseeable future. Efforts also need to be made to use green energy sources for power generation and integrate them with $\mathrm{CO}_{2}$ capture and utilization processes (Roh et al. 2016a).

[Insert Table 1 here]

\section{3. $\mathrm{CO}_{2}$ Emissions and Management}

Due to the various anthropogenic activities, it is very difficult to maintain the $\mathrm{CO}_{2}$ concentration in atmosphere at acceptable levels. Most of the research has been aimed at addressing this problem through CCS and CCU techniques. A number of authors have reviewed the technologies and current challenges with respect to CCS (Li, et al. 2013; Rahman, et al. 2017) and CCU (Almomoori, et al 2017; Karimi and Kawi, 2016; Lin and Biddinger, 2017; Yuan, et al. 2015; Kongpanna et al. 2015; Roh, et al. 2016a). The approach primarily being employed is to manage the $\mathrm{CO}_{2}$ concentrations after it has been released, that is "cure" the problem. With this approach, there are two main concerns: how to capture the released $\mathrm{CO}_{2}$ and then what to do with it?

\subsection{Capture technologies}

The industrial sector alone accounts for about $50 \%$ of the total $\mathrm{CO}_{2}$ emissions. The concentration of $\mathrm{CO}_{2}$ in flue gas emissions from stationary sources is relatively high compared with other mobile sources. Therefore, preventing the emission of $\mathrm{CO}_{2}$ from stationary sources is a feasible option to control the global $\mathrm{CO}_{2}$ concentration. To capture $\mathrm{CO}_{2}$ from stationary sources and the atmosphere, different mass transfer techniques may be used including absorption, adsorption and membrane separations. Techniques are well established to capture $\mathrm{CO}_{2}$ at the different stages (post combustion or pre combustion) for emissions from stationary sources, i.e., mainly from chemical processes and power plants. $\mathrm{CO}_{2}$ capture from air (dynamic source), however, is very challenging because of thermodynamic limitations resulting from the extremely dilute $\mathrm{CO}_{2}$ concentrations, and the energy cost for driving large volumes of air through a capturing process. Classical $\mathrm{CO}_{2}$ separation processes such as cryogenic distillation and membrane-based separation are not economically competitive. During the past several years, numerous contributions have been devoted to evaluating different approaches for $\mathrm{CO}_{2}$ capture from the ambient air (Lackner, et al. 1999; Kulkarni \& Sholl, 2012; Sehaqui, et al. 2015). Another option worth investigating is enhancing the engineered cultivation of biomass, which can then be used as a raw material for biofuel production (Rodionova, 2017).

Pre-combustion: In pre-combustion capture process $\mathrm{H}_{2}$ and $\mathrm{CO}_{2}$ are produced from fuel gasification followed by water gas shift reaction. Well established processes are available to separate $\mathrm{CO}_{2}$ from the flue gas by physical absorption using selexol or rectisol solvents (IEA, 2016). Research is in progress to synthesize efficient sorbents and membranes to overcome the challenges associated with these technologies at commercial scale implementation (Bolisetty, et al. 2015; NETL/DOE. 2015). 
Oxy-fuel combustion: The combustion processes utilize pure oxygen rather than air. Therefore, the exhaust gas contains mainly $\mathrm{CO}_{2}$ and water vapor that can be easily separated to $\mathrm{CO} 2$ and water by condensation. Oxygen-fuel combustion avoids complex post-combustion separation and have higher power generation efficiencies. The main disadvantages associated with oxy-fuel combustion are oxygen separation and repowering (Kocs, 2017). Most of the studies on oxy-fuel combustion are at laboratory or small scale and these technologies need be demonstrated at a large scale such as power plants (Ferrari, et al. 2017).

Post-combustion: In post-combustion capture process, $\mathrm{CO}_{2}$ is separated from flue gas consisting of high amounts of $\mathrm{N}_{2}$. At present the amine based post combustion capture process is considered to be the most mature technique among all solvent based $\mathrm{CO}_{2}$ capture processes. However, active research is striving towards process improvement to address the issues such as: effect of oxidized impurities, handling bulk volumes and energy requirement (Liang, et al. 2016). Membrane technology is also a potential option for post-combustion $\mathrm{CO}_{2}$ capture due to the inherent advantages: simple in operation, less energy requirement, compact size, stable at high acid concentrations and less water requirement (Khalilpour, et al. 2015). However, it is still not an economical option compared with solvent based capture in handling bulk volumes of captured gas. The challenges associated with membrane at high throughput are: permeability not as desirable, significant energy required to create vacuum/high pressure and interference of harmful contaminants (NETL/DOE. 2015). In the $\mathrm{CO}_{2}$ capture by adsorption processes, $\mathrm{CO}_{2}$ is adsorbed on a solid surface by physical/chemical adsorption followed by adsorbent exposed to high temperature or pressure swing to release the adsorbate. Extensive studies are being carried out using different adsorbents - including metal organic frameworks, zeolites, sodium oxides, amine-enriched sorbents and carbonates to synthesize the efficient process prototype with following characteristics: high adsorption capacity, low cost, high selectivity, thermal stability, chemical stability, low attrition rates (Samanta, et al. 2012; Yaumi, et al. 2017). In addition to the above techniques, the use of ionic liquids and hybrid approaches are being explored rigorously to intensify the $\mathrm{CO}_{2}$ capture process (Liu et al. 2016).

Perspectives: Research during the last two decades on carbon capture from stationary sources has reached a high level of sophistication. It is possible to capture the maximum amount of $\mathrm{CO}_{2}$ using techniques that are continuously being improved. In order to mitigate the $\mathrm{CO}_{2}$ concentration in atmosphere, the captured $\mathrm{CO}_{2}$ from industries (about $50 \%$ of the total emission) has to be sequestrated and utilized. However, the enormity of this problem with present limitations on sequestration and utilization techniques raises the questions - would it be viable to sequestrate large volumes of $\mathrm{CO}_{2}$ or convert it to useful products?

\subsection{Sequestration technologies}

There is without doubt a need for reduction of $\mathrm{CO}_{2}$ concentration in the atmosphere and an alternative already being tried is to capture the $\mathrm{CO}_{2}$ from emission sources and then sequestrate it (see Figure 2). Storage or sequestration involves the transportation of the captured and pressurized $\mathrm{CO}_{2}$ to storage tanks or the injection into underwater formations and other 
underground options (IPCC, 2005). The storage in geological formations and mineralization are the most frequently discussed; especially the option for use in oil fields as geological storage and the use in mineralization using cement emissions (IPCC, 2005). There have been projects involving the use of $\mathrm{CO}_{2}$ as storage in Enhanced Oil Recovery (EOR) as is the case in Canada at the Boundary Dam Facility (Consoli and Wildgust, 2017). In addition, there are industrialized sequestration projects in the North Sea and other offshore basins (Consoli and Wildgust, 2017). However, this, ultimately, does not solve the problem of $\mathrm{CO}_{2}$ concentrations in the atmosphere as they are merely relocated to long-term storage options, from which the $\mathrm{CO}_{2}$ will come out again. In addition, large scale deployment of CCS is associated with following challenges: energy requirement, capture cost, transport infrastructure availability, geological storage availability, technical and integration risks and public perception (REN21, 2017). As a consequence, there is a clear shift towards CCU because of its advantages over CCS. However, the challenges associated with CCU have to be further addressed in more detail.

\subsection{Conversion technologies}

Conversion of $\mathrm{CO}_{2}$ to useful products is limited by, for example, lack of knowledge about the products that can be made by converting $\mathrm{CO}_{2}$, about the catalysts that may be needed, and the associated reaction kinetics. Therefore, most carbon dioxide conversion technologies are currently in their early stages of development. As a result of this, carbon dioxide conversion processes have been limited to the production of bulk chemicals like methanol, syngas or dimethyl carbonate, although in principle, hundreds of chemicals can be produced through carbon dioxide conversion reactions (Otto et al., 2015). There are almost no process-level studies dealing with production of $\mathrm{CO}_{2}$-based fine chemicals. Also, there exist only limited industrial application cases, like the $\mathrm{CO}_{2}$-based methanol plants in Iran (Aasberg-Petersen et al., 2008), Qatar (Al-Hitmi, 2012) and Iceland (Carbon Recycling International, 2016). Some of the useful products that can be obtained by converting $\mathrm{CO}_{2}$ have been studied recently by Roh, et al. 2016ab and Bertran, et al. 2017.

Industrially, conversion processes have been used for the production of urea and certain carbonates (Mikkelsen, 2010). However, the development of this technology to other products is relatively limited; methanol production is the most mature technology. In addition, the amount of $\mathrm{CO}_{2}$ that can be converted is severely hampered by the supply-demand scenario of these useful products. Even if the conversion processes to different products are mature enough and sustainable enough, the amount of emissions that can be reduced is still limited by the demands of all these products. If the production of all these products were replaced by conversion processes, only about $1 \%$ of emissions would be reduced (Frauzem et al., 2017). This amount could be greatly increased if more sustainable routes to fuels could be found. In this respect conversion of $\mathrm{CO}_{2}$ into biofuel can offer an attractive solution. However, any such conversion process should be sustainable and result in a net negative $\mathrm{CO}_{2}$ emission. 


\section{4. $\mathrm{CO}_{2}$ emission reduction technologies}

This option looks at the core of the $\mathrm{CO}_{2}$ management problem - that is, how to reduce the current levels of $\mathrm{CO}_{2}$ emission by more efficient use of energy? The list of energy using equipment and processes are many and therefore, in this paper only a few major ones are considered briefly and one (chemical processes) considered in greater detail.

Transportation: Gasoline and other liquid fuels are primary sources of fuel for transportation vehicles. In 2012, total 104 quadrillion Btu of energy is consumed by transportation sector and the energy consumption is expected to reach 155 quadrillion Btu by the year 2040 in this sector (The International Energy Outlook, 2016). At present fossil fuels are being used as a primary energy source for vehicles. In order to limit the global temperature rise to $2^{0} \mathrm{C}$, the emission from transportation sector should be reduced by $21 \%$ of the total emissions relative to the 4 degree scenario by the year 2050 (IEA, Global EV Outlook. 2013). Research is more focused towards the development of biofuels (Bio-ethanol and diesel) and blends to replace the use of fossil fuels. The biofuels are more favorable to sustainable environment as they emit less $\mathrm{CO}_{2}$ compared to fossil fuels. However, the entire world's attention is towards the use of electric vehicles, which will eventually reduce dependence on petroleum and biofuels. In the long-term, the use of electric vehicles decarbonizes the entire transportation sector. At present the market transformation is constrained by the challenges in the following fields: technical, financial, policy challenges and market fluctuations.

Equipment: The equipment, which alters the pressure and temperature of systems, may require significant energy input. Turbines, pumps, compressors and heat exchangers, etc., handle energy intensive tasks at the industrial level. Improvements in technology: steps towards equipment efficiency increase, compact design, equipment integration, cogeneration and heat integration, etc. will increase the overall performance. These steps along with energy auditing will conserve the energy and leads to less $\mathrm{CO}_{2}$ emissions. Process design that may reduce the energy demand for any equipment may also be considered as a means for $\mathrm{CO}_{2}$ emission reduction.

Residential: The total energy consumption by the residential sector is significantly high and consistently increasing with time. As per "The International Energy Outlook 2016 projections", the energy use in residential sector will account for about $13 \%$ of the world total delivered energy consumption by 2040 . The energy consumption is due to the following activities: cooling, heating, lighting, and consumer products. The energy consumption in the residential sector can vary significantly from region to region because of geographical variations, energy access, equipment efficiency, and income levels. The energy consumption in this sector can be significantly reduced by using advanced and cost effective technologies such as: use of LED's for lighting, centralized heating systems, use of high efficient consumer products including heat pumps, water heaters, air conditioners, dish washers and electric stoves. Engineered construction and retrofitting of structures with the objective of energy conservation and encouraging the use of energy from renewables will be able to reduce the carbon foot print. In addition to this people should be self-motivated and socially responsible towards the energy saving which can create sustainable environment by minimizing $\mathrm{CO}_{2}$ emissions. 
Chemical processes: Industrial sector including manufacturing and non-manufacturing units account for $54 \%$ of total world delivered energy which is the maximum compared with any other end-use sector (The International Energy Outlook, 2016). Most of the chemical industries are known as energy intensive manufacturing units which include: petrochemicals, pulp and paper, basic chemicals, refining, nonferrous metals, iron and steel, nonmetallic minerals and food. Basic chemical industries are the largest consumer of delivered energy compared with all other energy intensive industries. Many of the chemical processes (distillation, evaporation, drying, etc.) require energy at high temperature, which can be facilitated by using renewable or fossil fuel energy. Chemical industries have extensive use of auxiliary equipment such as: pumps, compressors and conveyers, which also require significant amounts of high grade energy.

Until last two decades the chemical process industries were designed using traditional methods and the main focus was on primary tasks (reaction \& separation) and economics (Hernandez, 2017). At present, the energy consumption and waste release in manufacturing industries are serious concerns that need to be addressed to avoid the disruption of environmental cycles which in turn make the process sustainable. Therefore, currently the vison of sustainable process design is to conceptualize new processes considering reactions, separations and economics along with energy conservation, safety, environmental and social impacts. Recent publications highlighting integrated solution approaches (Celebi et al, 2017; Roh et al, 2016a, Yue \& You, 2014) are options worth investigating.

\subsection{Perspectives on $\mathrm{CO}_{2}$ emission and management}

Mature technologies are available for $\mathrm{CO}_{2}$ capture and sequestration. $\mathrm{CCS}$ is one of the potential options to mitigate the climate change. However, different technical and economic issues must first be resolved in order to use this option on a large scale. CCS is perceived to be an unprofitable activity that requires large capital investment and energy (Cuellar-Franca and Azapagic, 2015), while delaying the problem and not resolving it. As an alternative to CCS, $\mathrm{CCU}$ is considered to be a more attractive option as it adds value to the captured $\mathrm{CO}_{2}$ by producing useful chemicals. In CCU process, the captured $\mathrm{CO}_{2}$ could also be used as a $\mathrm{C} 1$ building block for producing high carbon number compounds. However, the CCU technologies are not implemented on a large scale (Yuan, et al. 2016), although, Hasan et al. (2014) and Gencer et al. (2015) have reported substantial and interesting new developments. Also, exactly how much of the captured $\mathrm{CO}_{2}$ may be converted to useful chemicals with negative or zero net $\mathrm{CO}_{2}$ emission needs to be established.

Additionally, research is also focused on improvisation of energy technologies through innovative and sustainable designs to substantially reduce the $\mathrm{CO}_{2}$ emissions (EIA, 2015; Tula, et al. 2017). For example, a global increase of $7 \%$ in the efficiency of coal-fired power plants will reduce the global carbon dioxide emissions by 1.7 billion tons per year (World Energy Resource, 2016). 
A summary on $\mathrm{CO}_{2}$ emission and management towards the creation of a sustainable environment by 2050 is given in Table 2 in terms of selected variable values. The energy related $\mathrm{CO}_{2}$ emissions need to be reduced significantly by 2050 . To meet this target the following alternatives need to be encouraged judiciously: use of renewable, green and nuclear energy, CCS and CCU for $\mathrm{CO}_{2}$ capture, fuel switching and energy efficient technologies. The impact on cumulative $\mathrm{CO}_{2}$ reduction by $\mathrm{CCS}$ and $\mathrm{CCU}$ technologies need to be significant. But, the $\mathrm{CO}_{2}$ emission reductions by energy efficient technologies have higher impact compared with capture technologies. To meet the target energy reduction technologies need to double the global rate of improvement in energy efficiency by 2030 (UN, 2015). Energy generation technology in thermal power plants is fully matured and there is little scope to improve the energy efficiency. Also, energy efficiency of industrial, transportation and building sectors need to be improved significantly to reduce the cumulative $\mathrm{CO}_{2}$ emissions. The industrial sector alone has the target of $120 \mathrm{Gt}$ of cumulative $\mathrm{CO}_{2}$ reduction by improving the energy efficiency (EIA, 2015). Therefore, the research should be more focused on sustainable chemical process synthesis, design and innovation to reduce the energy consumption.

[Insert Table 2 here]

\section{Sustainable Chemical Process Design}

Process systems engineering (PSE) has evolved into becoming a field of chemical engineering, that can provide systematic methods and tools for sustainable and innovative synthesis-design of chemical and biochemical processes. Different solution approaches may be applied to determine sustainable process designs: hierarchical methods based on heuristics (Klemes, et al. 2013); mathematical optimization methods (Chen and Grossmann, 2017); hybrid-integrated methods based on process intensification (Babi, et al. 2015), based on superstructure optimization of biorefinery (Bertran, et al. 2017), and, $\mathrm{CO}_{2}$ capture-utilization (Frauzem, et al 2017). Figure 8 shows different levels of boundaries that have to be considered in process design to analyze the sustainability at every stage. Sustainability is measured in terms of, among others, usage of energy, water, material; environmental impacts as well as economic and social factors. With respect to energy consumption and $\mathrm{CO}_{2}$ emission, the sustainability of a new innovative/alternative process need to be established in terms of energy consumption, environmental impacts as well as overall profit while converting the same raw material to the same products. The resulting process design should also be sustainable with respective to safety, operability and other sustainability-LCA factors. In this paper sustainable process design is highlighted through the application of an extended version (Bertran, et al. 2017) of a 3-stages sustainable process synthesis-design methodology (Babi, et al. 2015).

[Insert Figure 8 here]

The objective of sustainable process design is not to create additional burden on the $\mathrm{CO}_{2}$ management problem by releasing more $\mathrm{CO}_{2}$ than necessary. That is, process synthesis-design alternatives are to be determined that either reduces the energy demand significantly through retrofit design (providing a very good solution to "curing" the problem); generates alternative 
fuels-chemicals through renewable sources (providing a very good solution to "curing" or "preventing" the problem); and integrated and sustainable CCU process synthesis-design that "prevents" the problem through zero or net negative $\mathrm{CO}_{2}$ emission. In all cases, non-tradeoff solutions are sought with respect to economic, environmental and energy indicators.

\subsection{Energy versus sustainability}

Energy (demand and supply) is directly related to the sustainability of any chemical or biochemical process. Energy consumption increases as energy demand for running the process increases. As energy consumption increases, the carbon-footprint as well as the cost of operation increases. It is possible therefore to obtain non-tradeoff process designs for many chemical and biochemical processes.

Distillation is one of the most widely used separation techniques in the chemical process industry. As a separation technique, it is also one of the most energy intensive, while from an efficiency point of view, it is among the processes having the least thermal efficiency (Pellegrino, et al. 2004). Thermal efficiency is defined as the ratio of the net work to the heat supplied by combusted fuel. Even though distillation is ranked among the processes with the least thermal efficiency, nearly $80 \%$ of all vapor-liquid separations in chemical process industries are performed by distillation (Wankat, 2007). According to the US Department of Energy, separation technologies from all the manufacturing industries used nearly 150 million $\mathrm{kW}$ in 2005 (Angelini, et al. 2005), out of which, distillation (49\%), drying (20\%) and evaporation (11\%) accounted for more than $90 \%$ of the total energy consumption. It is estimated that the United States alone has more than 40,000 distillation units operating in more than 200 different processes (Angelini et al., 2005), which clearly points to distillation as a significant contributor to the overall energy consumption. Therefore, design of new vapor-liquid separation systems or retrofitting existing systems must be considered for more energy efficient options and sustainable solutions. One such option is to use hybrid separation systems, which combine one or more low energy consuming separation techniques with the higher energy consuming distillation in such a way that a target separation can be achieved at significantly lower energy consumption. Hybrid schemes involving membrane-based separation with distillation have been proposed by many. For example, Stephan et al. (1995), Pettersen et al. (1996), Davis et al. (1993), Moganti et al. (1994) and Caballero et al. (2009) proposed hybrid schemes for recovery of olefins. Also, Rautenbach and Albrecht (1985) highlighted the application of hybrid schemes for separation of an azeotropic mixture of benzene-cyclohexane, while Goldblatt and Gooding (1988) highlighted the application of hybrid schemes to separate an azeotropic mixture of ethanol-water. The main questions, however, are when such hybrid schemes should be applied, what characteristics the separation problem should have, what the configuration should be and how much improvement could be expected?

Tula et al (2017) recently proposed a general method for synthesis-design of hybrid distillationmembrane based separation schemes taking into account the mixture to be separated, the difficulties of using only distillation or membrane-based operations to achieve the desired 
separation, the optimal distillation-membrane based hybrid scheme, the potential for energy saving without compromising the product specifications, and the capital and operating costs. For several test cases, Tula et al. (2017) showed substantial decreases in energy consumptions while matching the same product purity specifications.

\subsection{Environmental impact versus sustainability}

Solvent based separations are widely used in process industries to extract components from different mixtures, including valuables from waste, API's, and fine chemicals. In addition to the aqueous phase extraction, organic solvents such as alcohols, ketones, volatile organic compounds (VOCs), aldehydes and some esters are the most frequently used solvents in industries. To replace the toxic organic solvents and enhance sustainability in separation processes, research is focused on synthesis and use of green solvents such as bio-derived solvents (Li, et al. 2016), supercritical fluid $\mathrm{CO}_{2}$ (Ramsey, et al. 2009), ionic liquids and eutectic mixture (Penn-pereria and Namiesnik, 2014). Gani, et al. 2006 proposed model based methods and tools for selection of solvents, considering process performance, economics and environmental aspects. This methodology avoids most of the experimental burden on selection of the solvent. Mitrofanov, et al. (2012) presented a framework for solvent selection and design. The framework consists of several modules which can handle different aspects of solvent extraction processes. Carvalho et al. (2013) and Garcia et al. (2016) showed that selection of the appropriate solvent not only reduces the environmental impact, but also increases profit through reduced energy consumption and therefore, also reduced carbon foot-print. Papadakis, et al. (2016) proposed a systematic methodology for solvent selection to execute solvent swap task in pharmaceutical processes. The method incorporates a pharmaceutical solvent database, tools for calculating properties of solvents and the process models of batch distillation and crystallization to perform the swap task.

\subsection{Achieving sustainability through process intensification}

Process intensification is development of a process/equipment that leads to improvement of reaction kinetics/energy efficiency/process safety and/or reduction in equipment size/waste generation/product cost (Stankiewicz and Moulijn, 2000; Reay, et al. 2008; Ponce-Ortega, 2012; Lutze et al, 2013). Process intensification can be applied at different scales in process system engineering (Lutze et al. 2013): unit operations scale (equipment used in process flowheet to represent the operations performed in the processing route), task scale (different tasks performed, for example, reaction and separation tasks) and phenomena scale (the phenomena involved within a task that needs to be performed). Process intensification in these three scales and interlinking to each other, with the overall improvement of the process as an objective, has the potential to generate new and innovative more sustainable process alternatives compared to a "base case" design. Babi, et al. (2014) reported several highly improved non-tradeoff solutions with respect to energy consumption, carbon footprint, profit as well as other performance (sustainability) factors for methyl acetate and dimethyl carbonate processes. 
Process intensification also accounts for process integration, which can be applied at process level in the following form: heat integration ( $\mathrm{Yu}$, et al. 2017), mass integration (Klemes, et al. 2013), scheduling and supply chain management (Verderame and Floudas, 2009).

\subsection{Sustainable process design for prevention}

For synthesis and design of $\mathrm{CO}_{2}$ utilization processes, Roh, et al. 2016a presented a methodology, containing three stages. In process synthesis stage, a network of $\mathrm{CO}_{2}$ utilization processes are developed using superstructure optimization approach; setting of targets for process improvement, and identifying new process design alternatives that "prevent" the $\mathrm{CO}_{2}$ emission problem.

Use of optimization-based techniques during process synthesis and design allows to consider simultaneously multiple issues and to obtain optimal matches of raw material, processing technologies and product, hence leading to processing routes that not only are economically attractive, but also ensure an efficient use of raw materials and minimized waste and emissions. Bertran, et al. (2017) proposed a generic methodology for sustainable synthesis and design of processing routes. This consists of three stages: In stage-1, super structure optimization is performed to find the optimal processing route using data related to process, compounds, economics and environmental issues. A computer aided tool Super-O (Bertran, et al. 2016) is developed to guide the user with data management and data transfer to GAMS (Corporation, 2013) software for execution. In stage-2, the detailed design of optimal process path is performed along with identification of bottle necks of the process and scope for innovations. In stage-3, process intensification methodology is proposed to come up with unique, innovative and more sustainable process designs.

This 3-stages sustainable process design has been applied for biorefinery network synthesis (Bertran et al. 2017); net CO2 emission based CCU process design for value added chemicals (dimethyl carbonate, methanol, dimethyl ether, succinic acid) production (Frauzem et al. 2017) as well as chemical process design and wastewater network optimization. All these solutions point to "prevention" of the $\mathrm{CO} 2$ emission problem rather than curing it afterwards.

\section{Application Examples}

In this section, four examples of sustainable chemical process design are given to highlight the issues of energy-sustainable design, energy-CO2 neutral design, energy-retrofit design, and energy-process intensification. In all cases it was possible to obtain non-tradeoff solutions. In all examples, the objectives are to reduce energy consumption, carbon foot-print (indirectly and directly reducing $\mathrm{CO} 2$ emission) and production costs without affecting negatively any other

performance indices. The solution approach used in all cases is the extended 3-stage framework for sustainable process design (Bertran et al., 2017). 


\subsection{Energy-sustainable process design}

A relevant example for the transition from oil- to biomass-based fuel is ethanol. Whereas it can be used as fuel on its own, it can also be blended with gasoline, which is currently done in various countries to promote sustainability and as a transition towards more renewable transportation fuels (Renu, et al. 2016; Mofijur, et al. 2016). The case of conversion of biomass to useful products, including energy is highlighted in this example. An important aspect towards the shift from fossil-based sources to renewables for energy is the appropriate selection of feedstock, processing route and products by considering all the relevant aspects (economics, limited biomass availability at different locations, given energy demand, technology maturity, etc.). Figure 9 highlights a biorefinery network for multiple biomass sources and multiple products that has been created based on known information on biomass pretreatment, conversion steps, and separation steps. The vertical columns indicate processing steps and the boxes within each step indicate the known technologies that may be applied. The boxes on the left represent the different biomass available and the boxes on the right indicate products that may be obtained. That is, the sources are linked to multiple processing technologies classified in terms of alternatives available within the processing steps. By solving the profit optimization problem, a processing route (feedstock-process-product) is obtained, which converts available material to desired products, satisfies supply-demand constraints, has higher profit and lower environmental impact. Therefore, once a network (superstructure) is created, different problems can be formulated and solved.

[Insert Figure 9 here]

The application of the superstructure optimization based technique for processing route synthesis is highlighted here for multiple biomass feed-stocks (wheat straw, corn stover, sugarcane bagasse, switch grass, hardwood chips, and cassava rhizome) available at different geographic locations for the production of ethanol. Note that network (see Figure 10) considered for this problem is a subset of the network of Figure 9. The method employed allows the consideration of different feed-stocks, processing steps, process technologies available for each processing step and the products and by-products, as highlighted in Figure 10. The method allows the simultaneous consideration of different aspects (location, feed-stock availability, CAPEX, OPEX, operational limitations, etc.) involved in the design, therefore leading to sustainable solutions ensuring a profitable process, efficient raw material use, minimal waste and reduced emissions. Therefore, through assisting the decision making involved in design with a systematic optimization-based methodology, sustainable solutions can be obtained. The resulting MINLP or MILP problem is formulated and solved through Super-O, which employs GAMS as the numerical solver. Super-O allows the generation of different versions of the synthesis problem evaluating different scenarios for synthesis, design, operation, and manufacturing objectives. That is, given the data and performance criteria (objective function), the best processing route for a given scenario can be determined.

[Insert Figure 10 here] 
Bertran et al (2017) highlights several optimal scenarios in terms of the optimal biomass (together with the location of the biomass availability) for the cheapest production costs (including annualized capital cost). The combination of sugarcane bagasse (feedstock), no limits on feed-stock availability and Thailand (production location) gives the cheapest dehydrated ethanol (fuel grade). Table 3 summarizes the results for different location scenarios studied.

[Insert Table 3 here]

A new case, considering limits on feedstock availability, feedstock location, transportation costs for multi-location production, however, gives interesting new results. A selection of these new results is given in Table 4. In this case, the processing route is fixed and optimization is used to determine the choice of raw material(s) and allocation of raw material purchase, product sale, and process allocation, where the process has been divided into two sections, pretreatment (prefermentation) and processing (fermentation to purified product), which can be allocated to different geographical locations. It is observed that, since transportation costs are taken into account, changes in the feedstock availability and product demand greatly affect the selection of raw materials and locations, which are reflected in the overall economic profit (used as objective function). The optimal solution from Table 3 is no longer feasible (because of the limit on feedstock availability). Information related to the processing route data for the optimal solutions corresponding to various scenarios studied can be obtained from the authors.

[Insert Table 4 here]

\subsection{Energy- $\mathrm{CO}_{2}$ neutral designs}

The 3-stages framework for sustainable process design has been adopted for sustainable design of CCU processes by Bertran et al. (2017). Figure 11 highlights a superstructure of alternative processing routes for captured $\mathrm{CO}_{2}$ as the feedstock and various products, such as methanol, dimethyl ether, dimethyl carbonate, ethylene glycol and propylene glycol. The optimal processing route together with the product that maximizes the profit and provides a net $\mathrm{CO}_{2}$ negative emission is also highlighted in Figure 11 (Frauzem et al., 2017): the route to produce dimethyl carbonate is shown through the shaded boxes. The optimal processing routes for each value added product has also been determined in order to determine the total reduction of net $\mathrm{CO}_{2}$ emissions. Considering all the conversion processes available within the superstructure, the net $\mathrm{CO}_{2}$ emission would reduce the equivalent of around 60 power plants (considering an average power-plant as an $150 \mathrm{MW}$ coal-fired power plant emitting 1.5 million tons of carbon dioxide, as well as the current demand of the value-added products). Figure 12 highlights this result where the y-axis indicates the number of power plants, in this case $150 \mathrm{MW}$ coal-fired power plants is considered, whose emissions can be avoided and the $\mathrm{x}$-axis indicates the optimal route for a certain product.

[Insert Figure 11 here]

Insert Figure 12 here] 
The processing route for one of the value added chemicals, dimethyl carbonate is further investigated in this paper. The production of dimethyl carbonate (DMC) from carbon dioxide via ethylene carbonate is found to be the optimal processing route. This route is then designed and analyzed in detail (stage-2 of the 3-stage methodology), as depicted by the flow diagram in Figure 13. The capture process has been optimized to reduce the energy requirement of the desorption process to make it more sustainable. Information related to the detailed design for the integrated DMC process together with the processing route data can be obtained from the authors. Note that the purity of the carbon dioxide product is reduced to $97 \mathrm{~mol} \%$ resulting in almost 10 fold reduction of utility requirement and costs. Producing dimethyl carbonate via CO2 conversion according to the optimal processing route, gives a net carbon dioxide reduction of $\mathrm{CO} 2$ emissions by 0.09 tons per ton of dimethyl carbonate, considering the direct and indirect $\mathrm{CO} 2$ emissions of the capture process as well as the conversion process. A net reduction of 1.37 tons of carbon dioxide per ton of dimethyl carbonate is obtained when compared with a DMC production process not utilizing captured $\mathrm{CO} 2$. If world-wide production of DMC were thus replaced by this optimal processing route, a net $\mathrm{CO} 2$ emission reduction by about 1.5 million tons per year would be achieved. Disappointingly, this represents the $\mathrm{CO} 2$ emissions of only one $150 \mathrm{MW}$ coal-fired power plant (IPCC, 2005). Therefore, it is necessary to consider a network of processes to produce various products from conversion in conjunction with other energy saving technologies.

[Insert Figure 13 here]

\subsection{Energy-hybrid separations}

In this paper, the method of Tula et al (2017) is extended to a series of aqueous separations (water plus a second compound that may or may not form azeotrope with water.). The results for methanol-water separation are given in Table 5. These types of separations are particularly interesting when the water needs to be removed to obtain a high purity product. Clearly, as shown by Tula et al (2017), separation by distillation is not very energy efficient after certain product purity. Therefore, a hybrid scheme where distillation is performed until a cut-off point and then another separation technique (for example, membrane) that can perform the remaining separation at low energy consumption is employed. In the case of methanol-water separation, an actual membrane able to perform the separation and with reasonable permeability and selectivity has been found.

[Insert Table 5 here]

\subsection{Energy versus process intensification}

Applying the 3-stages sustainable design methodology (Babi et al. 2015), several new, innovative and more sustainable process designs have been reported recently: Anantasaran et al. (2017) for toluene methylation; Landero et al. (2017) for dioxolane production and Wisatwattanna et al. (2017) for ethylene glycol production. Table 6 gives details of the 
intensified processes for three well-known cases involving methyl acetate production; dimethyl carbonate production and biodiesel production.

[Insert Table 6 here]

\section{Conclusions}

The review of the data and its analysis point to the need for greater use of renewable, green and nuclear energy sources to meet the future demand of 815 quadrillion Btu in 2040, if the level GHG emissions are to be restricted to the established targeted limits. This would indeed be a "preventive" measure as these energy sources will release negligible amounts of GHG. However, continued use of fossil fuel sources, although unavoidable due to price, availability and established utilization techniques, should be reduced to a level such that the "curing" measures such as CCS, CCU or their combination can have a significant impact. For the industrial sector, and in particular, the energy intensive chemical and biochemical sector, sustainable process synthesis-design-intensification has shown that it is possible to obtain non-tradeoff solutions where profit is increased while at the same time, reducing energy consumption and $\mathrm{CO}_{2}$ emissions as well as improving other sustainability factors. This is a truly "predictive" measure as substantial reductions in energy consumption are possible to achieve without any negative effects on economy and/or environment. Also, in the case of retrofit design, new and innovative sustainable solutions are possible to obtain where the additional capital costs are minor and can quickly be covered through the increased profit without any negative impact on other sustainability factors. While some technologies are already available and many more will need to be developed, planned development where energy source, energy consumption together with their impacts need to be investigated to develop more sustainable solutions. Retrofit re-design of current energy intensive operations that significantly reduce the energy consumption is necessary and hybrid-operations (separations) as well as process intensification need to be employed. The problems to be solved need to include many inter-related factors and therefore improved and systematic methods and tools are needed to manage this complexity. Process systems engineering can play a very important role here by providing and further developing the needed

methods and tools. Finally, more effort and focus is needed at "preventive measures" instead of "curing measures" with respect to energy consumption and $\mathrm{CO}_{2}$ concentration management. 


\section{References}

Aasberg-Petersen, K., Nielsen, C.S., Dybkjær, I., Perregaard, J., 2008. Large Scale Methanol Production from Natural Gas. Haldor Topsoe.

Abbas, T., Bazmi, A.A., Bhutto, A.W., Zahedi, G., 2014. Greener energy: issues and challenges for Pakistan-geothermal energy prospective. Renew. Sustainable Energy Rev. 31, 258-269.

Adeolu, O.A., Olabanji, B.A., 2017. Renewable and non-renewable energy-growth-emissions linkages: Review of emerging trends with policy implications. Renew. Sustainable Energy Rev. 69, 275-291.

Al-Hitmi, K.M.R., 2012. QAFAC: Carbon dioxide recovery plant. Sustain. Technol. Syst. Policies, 22, 1-3.

Almamoori, A., Krishnamoorthy, A., Rownaghi, A.A., Rezaei, F., 2017. Carbon capture and utilization update. Energy Technol. 5, 834-849.

Amponsah, N.Y., Troldborg, M., Kington, B., Aalders, I., \& Hough, R.L. 2014. Greenhouse gas emissions from renewable energy sources: A review of lifecycle considerations. Renewable and Sustainable Energy Reviews, 39, 461-475.

Anantasaran N., Suriyapraphadilok, U., Babi, D. K., 2017, A computer aided approach for achieving sustainable process design by process intensification, Computers \& Chemical Engineering, 105, 56-73

Anselm, E., and Adam, B. 2014. Heating without global warming. International energy agency.

Ardizzon, G., Cavazzini, G., Pavesi, G., 2014. A new generation of small hydro and pumpedhydro power plants: Advances and future challenges. Renew. Sustainable Energy Rev. 31, 746-761.

Babi, D.K., Holtbruegge, J., Lutze, P., Gorak, A., Woodley, J.M., Gani, R., 2015. Sustain-able process synthesis-intensification. Comput. Chem. Eng. 81, 218-244.

Babi, D.K., Lutze, P., Woodley, J.M., Gani, R., 2014. A process synthesis-intensification framework for the development of sustainable membrane-based operations. Chem. Eng. Process. 86, 173-195.

Bahadori, A., Zendehboudi, S., Zahedi. G., 2013. A review of geothermal energy resources in Australia: current status and prospects. Renew. Sustainable Energy Rev. 21, 29-34.

Bertran, M.-O., Frauzem, R., Zhang, L., Gani, R., 2016. A generic methodology for superstructure optimization of different processing networks, Computer Aided Process Engineering, 38, 685-690.

Bertran, M., Frauzem, R., Sanchez-Arcilla, A.S., Zhang, L., Woodley, J.M., Gani, R., 2017. A generic methodology for processing route synthesis and design based on superstructure 
optimization. Comput. Chem. Eng. (In Press)

http://dx.doi.org/10.1016/j.compchemeng.2017.01.030

Bhattacharya, S.C., Salam, P.A., Pham, H.L., Ravindranath, N.H., 2003. Sustainable biomass production for energy in selected Asian countries. BIOMASS BIOENERG. 25, 471-482.

Bolisetty, S., Pathi, S., Inkollu, S., Kondapuram, V.R., 2015. Development trends in porous adsorbents for carbon capture. Environ. Sci. Technol., 49, 12641-12661.

Brundtland Commission. 1987. Report of the World Commission on Environment and Development: Our Common Future. Oxford University Press.

Carbon Recycling International, 2016. World's Largest CO2 Methanol Plant.

Carvalho, A., Matos, H. A., Gani, R., 2013, SustainPro - A tool for systematic process analysis, generation and evaluation of sustainable design alternatives, Computers \& Chemical Engineering, 50, 8-27

Celebi, A. D., Ensinas, A. V., Sharma, S., Maréchal, F. 2017. Early-stage decision making approach for the selection of optimally integrated biorefinery processes. Energy (In Press).

Chen, J., Jiang, F., 2015. Designing multi-well layout for enhanced geothermal system to better exploit hot dry rock geothermal energy. Renew. Energy, 74, 37-48.

Chen, Q., Grossmann, I.E., 2017. Recent developments and challenges in optimization-based process synthesis. Annu. Rev. Chem. Biomol. Eng. 8. 249-283.

CO2-Earth, 2017. Monthly CO2 Concentration [WWW Document].URL https://www.co2.earth/monthly-co2 (accessed 06.15.2017).

Consoli, C.P., Wildgust, N., 2017. Current Status of Global Storage Resources. Energy Procedia 114, 4623-4628. doi:10.1016/j.egypro.2017.03.1866

Corporation, G.D., 2013. General Algebraic Modeling System (GAMS) Release 24.2.1.

Creutzig, F., Ravindranath, N.H., Berndes, G., Bolwig, S., Bright, R., Cherubini, F. 2014. Bioenergy and climate change mitigation: an assessment. Glob. Change Biol. Bioenergy. 7, 916-944.

Cuellar-Franca, R.M., Azapagic, A., 2015. Carbon capture, storage and utilisation technologies: A critical analysis and comparison of their life cycle environmental impacts. J. CO2 Util. $9,82-102$.

Demirbas, M.F., Balat, M., Balat, H., 2009. Potential contribution of biomass to the sustainable energy development. Energy Convers Manag. 50, 1746-1760.

Devabhaktuni, V., Alam, M., Depuru, S.S.S.R., Green II, R.C., Nims, D., Near, C., 2013. Solar Energy: Trends and enabling technologies. Renew. Sustainable Energy Rev. 19, 555-564. 
Dowell, N.M., Fennell, P.S., Shah, N., Maitland, G.C., 2017. The role of CO2 capture and utilization in mitigating climate change. Nat. Clim. Chang. 7, 243-249.

Duflou, J.R., Sutherland, J.W., Dornfeld, D., Herrmann, C., Jeswiet, J., Kara, S., Hauschild, M., Kellens, K., 2012. Towards energy and resource efficient manufacturing: A processes and systems approach. CIRP ANN-MANUF TECH. 61, 587-609.

EIA, 2016. Monthly Energy Review, Total energy. US Energy Information Administration (EIA).

Elshout, P.M.F., Zelm, R.V., Balkovic, J., Obersteiner, M., Schmid, E., Skalsky, R., Velde, M. V., Huijbregts, M.A.J., 2015. Greenhouse-gas payback times for crop-based biofuels. Nat. Clim. Change. 5, 604-610.

Faik, B., Emrah, K., Umit, B., Sevda, K. 2017. Can biomass energy be an efficient policy tool for sustainable development?. Renew. Sustainable Energy Rev. 71, 830-845.

Ferrari, N., Mancuso, L., Davison, J., Chiesa, P., Martelli, E., Romano, M. C. 2017. Oxy-turbine for Power Plant with CO2 Capture. Energy Procedia, 114, 471-480.

Frauzem, R., Woodley, J.M., Gani, R., 2017. Application of a computer-aided framework for the design of $\mathrm{CO} 2$ capture and utilization processes, Computers Aided Chemical Engineering, 40, Elsevier B.V.

Fridleifsson, I.B., 2001. Geothermal energy for the benefit of the people. Renew. Sustainable Energy Rev. 5, 299-312.

Gani, R., Jimenez-Gonzalez, C., Ten Kate, A., Jones, M., Powell, L., Atherton, J.H., Cordiner, J.L. 2006. A modern approach to solvent selection, Chem. Eng. 30-43.

Garcia, M. G., Peraskeva, I., Tula, A. K., Babi, D. K., Gani, R., 2016, Tailor-made solvent and process design for the separation of azeotropic mixtures, Paper 374a, AIChE Annual Meeting, San Francisco, USA, 12-18 November 2016.

Gençer, E., Mallapragada, D. S., Maréchal, F., Tawarmalani, M., Agrawal, R., 2015, Round-theclock power supply and a sustainable economy via synergistic integration of solar thermal power and hydrogen processes, Proc. Natl. Acad. Sci. U. S. A., 112 (2015), 15821-15826

GWEC, 2012. Global wind 2011 report, Global Wind Energy Council.

GWEC, 2017. Global wind 2016 report. Global Wind Energy Council.

Hare, B., Schaeffer, M., Rocha, M., 2011. Science aspects of the $2^{\circ} \mathrm{C}$ and $1.5^{\circ} \mathrm{C}$ global goals in the Cancun Agreements, LDC paper series. Climate Analytics, Telegrafenberg, Germany.

Hernandez, E.M., 2017. Trends in sustainable process design from molecular to global scales. Current Opinion in Chemical Engineering. 17, 35-41. 
Hasan, M. M. F., Boukouvala, F., First, E. L., Floudas, C. A., 2014, Nationwide, regional, and statewide $\mathrm{CO}_{2}$ capture, utilization, and sequestration supply chain network optimization, Ind. Eng. Chem. Res., 53, 7489-7506.

Huber, M.T., 2009. Energizing historical materialism: fossil fuels, space and the capitalist mode of production. Geoforum. 40, 105-115.

Hussain, A., Arif, S.M., Aslam, M., 2017. Emerging renewable and sustainable energy technologies: State of the art. Renew. Sustainable Energy Rev. 71, 12-28.

IChemE. 2002. The Sustainability Metrics: Sustainable Development Process Metrics recommended for use in the Process Industries. IChemE, 2-30.

IEA, 2013. Technology Roadmap: Carbon Capture and Storage, International Energy Agency.

IEA, 2015. Energy Technology Perspectives. International Energy Agency.

IEA, 2016. 20 years of carbon capture and storage, International Energy Agency, 9 rue de la Federation, 75739 Paris Cedex 15, France.

IEA, 2017. Renewables information: Overview, International Energy Agency.

IEA, Global EV Outlook. 2013. Understanding the Electric Vehicle Landscape to 2020 (Paris: 2013), https://www.iea.org/publications/freepublications/publication/GlobalEVOutlook_2013.pdf.

IPCC, 2007. Climate Change 2007: Mitigation of Climate Change. Contribution of Working Group III to the Fourth Assessment Report of the Intergovernmental Panel on Climate Change. Cambridge University Press, Cambridge, United Kingdom and New York, NY, USA.

IPCC. 2005. Carbon Dioxide Capture and Storage. (B. Metz, O. Davidson, H. de Coninck, M. Loos, \& L. Meyer, Eds.). New York: Cambridge University Press.

IPCC. 2014. Climate Change 2014: Synthesis Report. Contribution of Working Groups I, II and III to the Fifth Assessment Report of the Intergovernmental Panel on Climate Change (Core Writing Team, R.K. Pachauri and L.A. Meyer (eds.)). IPCC, Geneva, Switzerland, $151 \mathrm{pp}$.

Jiang, L., Liandong, Z.H.U., Hiltunen, H., 2017. Large-scale geo-energy development: Sustainability impacts. Front. Energy. 1-7.

Kagel, A., Bates, D., Gawell, K., 2007. A guide to geothermal energy and the environment. Geothermal Energy Association, 42-58. www.geo-energy.org 
Kannan, N., Vakeesan, D., 2016. Solar energy for future world:- A review. Renew. Sustainable Energy Rev. 62, 1092-1105.

Kaplan,Y.A., 2015. Overview of wind energy in the world and assessment of current wind energy policies in Turkey. Renew. Sustainable Energy Rev. 43, 562-568.

Karakosta, C., Pappas, C., Marinakis, V., Psarras, J., 2013. Renewable energy and nuclear power towards sustainable development: Characteristics and prospects. Renew. Sustainable Energy Rev. 22, 187-197.

Karimi, I.A., Kawi, S., 2016. Technoeconomic perspectives on sustainable CO2 capture and utilization. Environmental Science and Pollution Research. 23, 22223-22225.

Khalilpour, R., Mumford, K., Zhai, H., Abbas, A., Stevens, G., Rubin, E.S., 2015. Membrane based carbon capture from flue gas: a review. J. Clean Prod. 103, 286-300.

Khan, N., Kalair, A., Abas, N., Haider, A., 2017. Review of ocean tidal, wave and thermal energy technologies. Renew. Sustainable Energy Rev. 72, 590-604.

Klemes, J.J., Varbanov, P.S., Kravanja, Z., 2013. Recent developments in process integration. Chem. Eng. Res. Des. 91(10), 2037-2053.

Kocs, E. A. 2017. The global carbon nation: Status of CO2 capture, storage and utilization. In EPJ Web of Conferences. 148, 00002. EDP Sciences.

Kongpanna, P., Pavarajarn, V., Gani, R., Assabumrungrat, S., 2015. Techno-economic evaluation of different $\mathrm{CO} 2$ - based processes for dimethyl carbonate production. Chem. Eng. Res. Des. 93, 496 - 510.

Kulkarni, A.R., Sholl, D.S., 2012. Analysis of Equilibrium-Based TSA Processes for Direct Capture of CO2 from Air. Ind. Eng. Chem. Res. 51, 8631-8645.

Kumar,Y., Ringenberg,J., Depuru, S.S., Devabhaktuni, V.K., Lee, J.W., Nikolaidis, E., Andersen, B., Afjeh, A., 2016. Wind energy: Trends and enabling technologies. Renew. Sustainable Energy Rev. 53,209-224.

Lackner, K.S., Grimes, P., Ziock, H., 1999. Carbon Dioxide Extraction from Air?; LAUR-995113; Los Alamos National Laboratory: Los Alamos, NM.

Landero, A. C., Gutiérrez, A. J., Gani, R., 2017, Development of an intensified reactive distillation process for the synthesis of dioxolane products, Computer-Aided Chemical Engineering, 40, (Elsevier - in press)

Li, L., Zhao, N., Wei, W., Sun, Y., 2013. A review of research progress on CO2 capture, storage, and utilization in Chinese Academy of Sciences. Fuel. 108, 112-130.

Li, Z., Smith, K.H., Stevens, G.W., 2016. The use of environmentally sustainable bio-derived solvents in solvent extraction applications - a review. Chin. J. Chem. Eng., 24, 215-220. 
Liang, Z., Fu, K., Idem, R., Tontiwachwuthikul, P., 2016. Review on current advances, future challenges and consideration issues for post-combustion $\mathrm{CO} 2$ capture using amine-based absorbents. Chin. J. Chem. Eng. 24, 278-288.

Lin, H., Biddinger, E.J. 2017. Challenges and opportunities for carbon dioxide utilization. Energy Technol. 5, 771-772.

Liu, X., Huang, Y., Zhao, Y., Gani, R., Zhang, X., Zhang, S., 2016, Ionic Liquid Design and Process Simulation for Decarbonization of Shale Gas, Industrial \& Engineering Chemistry Research, 55 (20), 5931-5944

Lutze. P., Babi, D.K., Woodley, J.M., Gani, R., 2013. Phenomena based methodology for process synthesis incorporating process intensification. Ind. Eng. Chem. Res. 52(22), $7127-7144$.

Mekhilef, S., Saidur, R., Safari, A., 2011. A review on solar energy use in industries. Renew. Sustainable Energy Rev. 15, 1777-1790.

Mikkelsen, M., Jorgensen, M., Krebs, F.C. 2010. The teraton challenge. A review of fixation and transformation of carbon dioxide. Energy \& Environmental Science, 3, 43-81. https://doi.org/10.1039/B912904A

Mishra, M.K., Khare, N., Agrawal, A.B., 2015. Small hydro power in India: Current status and future perspectives. Renew. Sustainable Energy Rev. 51, 101-115.

Mitrofanov, I., Sansonetti, S., Abildskov, J., Sin, G., Gani, R., 2012. The Solvent Selection framework: solvents for organic synthesis, separation processes and ionic-liquids solvents. In Symposium on Computer Aided Process Engineering. 17, 20-24.

Modi, A., Buhler, F., Andreasen, J.G., Haglind, F., 2017. A review of solar energy based heat and power generation systems. Renew. Sustainable Energy Rev. 67, 1047-1064.

Mofijur, M. Rasul, M.G., Hyde, J., Azad, A.K., Mamt, R., Bhuiya, M.M.K. 2016. Role of biofuel and their binary (diesel-biodiesel) and ternary (ethanol-biodiesel-diesel) blends on internal combustion engines emission reduction. Renew. Sustainable Energy Rev. 53, 265278.

Mohanty, S., Patra, P.K., Sahoo, S.S., Mohanty, A., 2017. Forecasting of solar energy with application for a growing economy like India: Survey and implication. Renew. Sustainable Energy Rev. 78, 539-553.

NETL/DOE,2015. Carbon dioxide capture handbook. U.S. National energy technology laboratory, department of energy. https://www.netl.doe.gov/File\%20Library/Research/Coal/carbon\%20capture/handbook/Car bon-Dioxide-Capture-Handbook-2015.pdf

NPE, 2017. Fusion Research: An Energy Option for Europe's Future, Directorate-General for Research, European Commission, 2007 (ISBN: 9279005138), Nuclear Fusion Power. 
2017. World Nuclear Association. http://www.world-nuclear.org/informationlibrary/current-and-future-generation/nuclear-fusion-power.aspx

OECD, 2012. OECD Environmental Outlook to 2050. The Consequences of Inaction. OECD, Paris, http://dx.doi.org/10.1787/9789264122246-en.

Omri, A., 2014. An international literature survey on energy-economic growth nexus: Evidence from country-specific studies. Renew. Sustainable Energy Rev. 38, 951-959.

Otto, A., Grube, T., Schiebahn, S., Stolten, D., 2015. Closing the loop: captured CO2 as a feedstock in the chemical industry. Energy Environ. Sci. 8, 3283-3297.

Ozturk, I., 2010. A literature survey on energy-growth nexus. Energy Policy. 38, 340-349.

Panwar, N., Kaushik, S., Kothari, S., 2011. Role of renewable energy sources in environmental protection: A review. Renew. Sustainable Energy Rev. 15, 1513- 1524.

Papadakis, E., Tula, A.K., Gani, R., 2016. Solvent selection methodology for pharmaceutical processes: Solvent swap. Chemical Engineering Research and Design, 115, 443-461.

Pena-Pereira, F., Namiesnik, J., 2014. Ionic liquids and deep eutectic mixtures: sustainable solvents for extraction processes. Chem. Sus. Chem. 7(7), 1784-1800.

Peschel, A., Jorke, A., Freund, H., Sundmacher, K., 2012. Model-based development of optimal reaction concepts for plant wide process intensification. Comput. Aided. Chem. Eng. 31, $150-154$.

Peters, G.P., Marland, G., Le, Q.C., Boden, T., Canadell, J.G., Raupach, M.R., 2012. Rapid growth in CO2 emissions after the 2008-2009 global financial crisis. Nat. Clim. Chang. 2, 2-4.

Pioro, I., Duffey, R., 2015. Nuclear power as a basis for future electricity generation. ASME J of Nuclear Rad Sci. 1, 011001-011019.

Ponce-Ortega, J.M., Al-Thubaiti, M.M., El-Halwagi, M.M., 2012. Process intensification: new understanding and systematic approach. Chem. Eng. Process. 53, 63-75.

Quaglia, A., Gargalo, C.L., Chairakwongsa, S., Sin, G., Gani, R., 2015. Systematic net-work synthesis and design: problem formulation, superstructure generation, data management and solution. Comput. Chem. Eng. 72, 68-86.

Quaglia, A., Sarup, B., Sin, G., Gani, R., 2012. Integrated business and engineering framework for synthesis and design of enterprise-wide processing networks. Comput. Chem. Eng. 38, 213-223.

Rahman, F.A., Aziz, M.M.A., Saidur, R., Bakar, W.A.W.A., Hainin, M.R., Putrajaya, R., Hasan, N.A., 2017. Pollution to solution: capture and sequestration of carbon dioxide (CO2) and 
its utilization as a renewable energy source for a sustainable future. Renew. Sustainable Energy Rev. 71, 112-126.

Rajcaniova, M., Kancs, D.A., Ciaian, P., 2014. Bioenergy and global land-use change. Appl. Econ. 46, 3163-3179.

Ramsey, E., Qiubai, S., Zhang, Z., Zhang, C., Wei, G., 2009. Mini-Review: Green sustainable processes using supercritical fluid carbon dioxide. Journal of Environmental Sciences, 21(6), 720-726.

Reay, D., Ramshaw, C., Harvey, A., 2008. In: Reay, D., Ramshaw, C., Harvey, A. (eds) Process intensification. IChemE, Rugby.

REN21, Renewables 2017: Global Status Report. 2017: Secretariat Renewable Energy Policy Network for the 21st Century (REN21). Paris.

Renu, S., Monika, S., Ashish, S. 2016. Environmental sustainability of bioethanol production from rice straw in India: A review. Renew. Sustainable Energy Rev. 54, 202-216.

Rodionova, M.V., Poudyal, R.S., Tiwari, I., Voloshin, R.A., Zharmukhamedov, S.K., Nam, H.G., Zayadan, B.K., Bruce, B.D., Hou, H.J.M., Allakhverdiev S.I., 2017. Biofuel production: Challenges and opportunities. 42, 8450-8461.

Roh, K., Frauzem, R., Nguyen, T.B.H., Gani, R., Lee, J.H., 2016(a). A methodology for the sustainable design and implementation strategy of $\mathrm{CO} 2$ utilization processes. Comput. Chem. Eng. 91, 407-421.

Roh, K., Frauzem, R., Gani, R., Lee, J.H., 2016(b). Process systems engineering issues and applications towards reducing carbon dioxide emissions through conversion technologies: Review. Chem. Eng. Res. Des. 116, 27-47.

Rourke, F.O., Boyle, F., Reynolds, A., 2010. Tidal energy update 2009. Appl. Energy. 87, 398409.

Rubin, E.S., Mantripragada, H., Marks, A., Versteeg, P., Kitchin, J., 2012. The outlook for improved carbon capture technology. Prog. Energy. Combust. Sci. 38, 630-671.

Samanta, A., Zhao, A., Shimizu, G.K.H., Sarkar, P., Gupta, R., 2012. Post-Combustion CO2 Capture Using Solid Sorbents: A Review. Ind. Eng. Chem. Res. 51, 1438-1463.

Segura, E., Morales, R., Somolinos, J.A., Lopez, A., 2017. Techno-economic challenges of tidal energy conversion systems: Current status and trends. Renew. Sustainable Energy Rev. 77, 536-550.

Sehaqui, H., Galvez, M. E., Becatinni, V., Tingaut, P., 2015. Fast and Reversible Direct CO2 capture from air onto all-polymer nano fibrillated cellulose polyethylenimine foams. Environ. Sci. Technol. 49, 3167-3174. 
Sharma, S.S., 2010. The relationship between energy and economic growth: Empirical evidence from 66 countries. Appl. Energy. 87, 3565-3574.

Shortall, R., Davidsdottir, B., Axelsson, G., 2015. Geothermal energy for sustainable development: A review of sustainability impacts and assessment frameworks. Renew. Sustainable Energy Rev. 44, 391-406.

Stankiewicz, A., Moulijn, J.A., 2000. Process intensification: transforming chemical engineering. Chem. Eng. Prog. 96(1), 22-24.

Teske, S., Pregger, T., Simon, S., Naegler, T., Graus, W., Lins, C. 2011. Energy [R] evolution 2010-a sustainable world energy outlook. Energy Effic. 4, 409-433.

The International Energy Outlook, 2016. U.S. Energy Information Administration. www.eia.gov/forecasts/ieo.

Tula, A.K., Befort, B., Garg, N., Camarda, K.V., Gani, R., 2017. Sustainable process design \& analysis of hybrid separations. Comput. Chem. Eng. 105, 96-104.

Uihlein, A., Magagna, D., 2016. Wave and tidal current energy - A review of the current state of research beyond technology. Renew. Sustainable Energy Rev. 58, 1070-1081.

UN, G. A. 2015. Transforming our world: The 2030 agenda for sustainable development. A/RES/70/1, 21 October.

Van Loo, S., Koppejan, J. 2008. The handbook of biomass combustion and co-firing. London: Earthscan.

Verderame, P.M., Floudas, C.A., 2009. Operational planning framework for multisite production and distribution networks. Comput. Chem. Eng. 33 (5), 1036-1050.

Wallace, M., Kuuskraa, V. 2014. Near-Term Projections of CO2 Utilization for Enhanced Oil Recovery. NETL.

Wisutwattana, A., Frauzem, R., Suriyapraphadilok, U., Gani, R., 2017, Intensification of ethylene glycol production process, Computer-Aided Chemical Engineering, 41, (Elsevier - in press)

WNN, 2017. Nuclear construction reaches 25-year high, World Nuclear News. http://www.world-nuclear-news.org/NN-Nuclear-construction-reaches-25-year-high$\underline{2806171 . h t m l}$

World energy resources. 2016. World energy Council. https://www.worldenergy.org/publications/2016/world-energy-resources-2016/

Yaumi, A.L., AbuBakar, M.Z., Hameed, B.H., 2017. Recent advances in functionalized composite solid materials for carbon dioxide capture. Energy. 124, 461-480. 
Yu, H., Eason, J., Biegler, L.T., Feng, X., 2017. Process integration and superstructure optimization of Organic Rankine Cycles (ORCs) with heat exchanger network synthesis. Comput. Chem. Eng. In Press.

Yuan, Z., Eden, M., Gani, R., 2015. Towards the development and deployment of large-scale carbon dioxide capture and conversion processes. Ind. Eng. Chem. Res. 55, 3383-3419

Yuan, Z., Eden, M.R., Gani, R., 2016. Toward the development and deployment of large-scale carbon dioxide capture and conversion processes. Ind. Eng. Chem. Res. 55, 3383-3419.

Yue, D., You, F., * \& Snyder, S.W. (2014). Biomass-to-Bioenergy and Biofuel Supply Chain Optimization: Overview, Key Issues and Challenges. Computers \& Chemical Engineering, 66, 36-56.

Zhang, L., Babi, D.K., Gani, R., 2016. New vistas in chemical product-process design. Annu. Rev. Chem. Biomol. Eng. 7, 557-582. 


\section{List of Tables}

Table 1: Energy resource availability and utilization statistics in 2015 year

Table 2: Perspectives on $\mathrm{CO}_{2}$ management in 2DS to 2050

Table 3: Optimal topology and objective function value (million USD) for each considered location - excluding capital costs (Bertran et al. 2017)

Table 4: Optimal feedstock/location selection and objective function value (million USD) for various scenarios - including transportation, multi-location options and capital costs

Table 5: Comparison of separation by distillation versus hybrid scheme for methanol-water mixture

Table 6: Details of new, sustainable and intensified processes 
Table 1: Energy resource availability and utilization statistics in 2015 year

\begin{tabular}{|c|c|c|c|}
\hline Energy & $\begin{array}{l}\text { Availability/ } \\
\text { capacity }\end{array}$ & Utilization & Remarks \\
\hline $\begin{array}{l}\text { Fossil fuels } \\
\text { Oil } \\
\text { Coal } \\
\text { Natural gas }\end{array}$ & $\begin{array}{l}1656 \mathrm{Bb} \\
891.531 \mathrm{Bt} \\
186874.7 \mathrm{Bcm}\end{array}$ & $\begin{array}{l}9.542 \mathrm{Bb} / \mathrm{Day} \\
7.8 \mathrm{Bt} / \text { year } \\
3538.6 \\
\text { Bcm/year }\end{array}$ & $\begin{array}{l}\text { Oil, coal and natural gas accounts for } 32.9 \% \text {, } \\
30 \% \text { and } 24 \% \text { of global primary energy } \\
\text { consumption respectively. They account } \\
4.1 \%, 39.3 \% \text { and } 22.9 \% \text { of required } \\
\text { electricity, respectively. In recent years, the } \\
\text { global coal production rate has been } \\
\text { decreasing while power generation from } \\
\text { natural gas and other renewable \& green } \\
\text { sources has been increasing. With an average } \\
\text { decrease of } 1 \% \text { per year in the coal } \\
\text { consumption, 50\% of the present coal } \\
\text { reserves will be exhausted by } 2100 \text {. }\end{array}$ \\
\hline Nuclear & $382.9 \mathrm{GW}$ & $2441331 \mathrm{GWh}$ & $\begin{array}{l}\text { Accounts for } 11 \% \text { of the total electricity } \\
\text { required. }\end{array}$ \\
\hline $\begin{array}{l}\text { Hydro } \\
\text { power }\end{array}$ & $1212.3 \mathrm{GW}$ & $3969115 \mathrm{GWh}$ & $\begin{array}{l}\text { Accounts for } 16.4 \% \text { of the total electricity } \\
\text { required. From } 2005 \text { to } 2015,39 \% \text { of growth } \\
\text { is reported in installed capacity. }\end{array}$ \\
\hline $\begin{array}{l}\text { Electricity } \\
\text { from solar }\end{array}$ & $227.101 \mathrm{GW}$ & $253000 \mathrm{GWh}$ & $\begin{array}{l}\text { Accounts for } 1 \% \text { of the total electricity } \\
\text { required. To increase this electricity share, } \\
\text { the capacity has to be expanded. With the } \\
\text { present technology this is not economical } \\
\text { and sustainable. }\end{array}$ \\
\hline Wind power & $431.948 \mathrm{GW}$ & $841231 \mathrm{GWh}$ & $\begin{array}{l}\text { Wind power accounts for } 7 \% \text { of total global } \\
\text { power generation capacity, which accounts } \\
\text { for } 4 \% \text { of the total electricity required. }\end{array}$ \\
\hline
\end{tabular}

Data Source: World Energy Resources, 2016. The International Energy Outlook, 2016. Units: Bb-Billion barrels, Bt-Billion Tons, Bcm- Billion cubic meter, GW- Giga Watt 
Table 2: Perspectives on $\mathrm{CO}_{2}$ management in 2DS to 2050

\begin{tabular}{|l|l|l|l|}
\hline Issues & $\begin{array}{l}\mathbf{C O}_{2} \text { emission/ } \\
\text { handling capacity }\end{array}$ & Target value & Remarks \\
\hline Total $\mathrm{CO}_{2}$ emission & $34 \mathrm{Gt} /$ year $(2015)$ & $14 \mathrm{Gt} /$ year $(2050)$ & $\begin{array}{l}\text { Energy related CO2 emissions } \\
\text { need to be zero by 2090. }\end{array}$ \\
\hline $\begin{array}{l}\mathrm{CO}_{2} \text { capture, storage } \\
\text { and utilization }\end{array}$ & $\begin{array}{l}0.120 \mathrm{Gt} / \text { year } \\
(2015)\end{array}$ & $90 \mathrm{Gt}^{*}$ & $\begin{array}{l}10^{3} \text { to } 10^{4} \mathrm{Gt} \text { of } \mathrm{CO}_{2} \\
\text { sequestration capacities are } \\
\text { necessary. }\end{array}$ \\
\hline $\begin{array}{l}\mathrm{CO}_{2} \text { emission } \\
\text { reduction } \\
\text { technologies }\end{array}$ & Not reported & $277 \mathrm{Gt}^{*}$ & $\begin{array}{l}\text { By introducing energy efficient } \\
\text { technologies this target need to } \\
\text { be achieved. Chemical Industry, } \\
\text { transportation and building } \\
\text { sectors are having high scope to } \\
\text { reduce the } \mathrm{CO}_{2} .\end{array}$ \\
\hline
\end{tabular}

Data source: IPCC, 2005; EIA 2015; * Cumulative $\mathrm{CO}_{2}$ reductions by 2050 
Table 3: Optimal topology and objective function value (million USD) for each considered location - excluding capital costs (Bertran et al. 2017)

\begin{tabular}{lllllllllll}
\hline Location & RM & WADD & PRET & HYD & FERM & BIOR & SEP1 & SEP2 & PROD & Profit \\
\hline Brazil & SB & ARP & ARP & NREL & ETOH & CENTR & BEER & BMIM & ETOH & 11.38 \\
Canada & WS & - & STEX & NREL & ETOH & CENTR & BEER & BMIM & ETOH & -28.78 \\
China & SB & DILAC & DILAC & NREL & ETOH & CENTR & BEER & BMIM & ETOH & 37.86 \\
India & SB & DILAC & DILAC & NREL & ETOH & CENTR & BEER & BMIM & ETOH & 82.13 \\
Mexico & WS & - & STEX & NREL & ETOH & CENTR & BEER & BMIM & ETOH & -4.46 \\
Thailand & CR & - & STEX & DILAC & ETOH & CENTR & BEER & BMIM & ETOH & 116.03 \\
USA & HWC & - & STEX & CONCA & ETOH & CENTR & BEER & BMIM & ETOH & 47.63 \\
\hline
\end{tabular}

\section{Abbreviations}

RM: raw material (CR: cassava rhizome, HWC: hardwood chips, SB: sugarcane bagasse, WS: wheat straw); WADD: water addition (ARP: ammonia recycled percolation, DILAC: dilute acid); PRET: pretreatment (ARP: ammonia recycled percolation, DILAC: dilute acid, STEX: steam explosion), HYD: hydrolysis (CONCA: concentrated acid, DILAC: dilute acid, NREL: enzymatic with NREL enzyme); FERM: fermentation (ETOH: ethanol fermentation); BIOR: biomass removal (CENTR: centrifuge); SEP1: separation step 1 (BEER: beer distillation); SEP2: separation step-2 (BMIM: extraction with ionic liquid BMIM-Cl); PROD: product (ETOH: fuel grade ethanol). 
Table 4: Optimal feedstock/location selection and objective function value (million USD) for various scenarios - including transportation, multi-location options and capital costs

\begin{tabular}{|c|c|c|c|c|c|c|c|c|c|c|}
\hline \multicolumn{3}{|l|}{ Scenario } & \multicolumn{2}{|l|}{ RM } & \multicolumn{4}{|c|}{ Location } & \multirow{2}{*}{$\begin{array}{l}\text { PROD } \\
\begin{array}{l}\text { Rate } \\
(\mathbf{k t} / \mathbf{y})\end{array}\end{array}$} & \multirow{2}{*}{$\begin{array}{l}\text { OF } \\
\text { Profit }\end{array}$} \\
\hline $\begin{array}{l}\text { EtOH rate } \\
(\mathbf{k t} / \mathbf{y})\end{array}$ & $\begin{array}{l}\text { RM AV } \\
(\mathbf{k t} / \mathbf{y})\end{array}$ & $\begin{array}{l}\text { PROD } \\
\text { DEM } \\
(\mathbf{k t} / \mathbf{y})\end{array}$ & Type & $\begin{array}{l}\text { Rate } \\
(\mathbf{k t} / \mathbf{y})\end{array}$ & $\mathbf{R M}$ & PRET & PROC & PROD & & \\
\hline 150 & No limit* & No limit* & WS & 703 & IN & IN & IN & MX & 150 & 95.30 \\
\hline 150 & 500 & 150 & $\begin{array}{l}\text { WS / } \\
\text { CS }\end{array}$ & $\begin{array}{l}500 / \\
203\end{array}$ & $\begin{array}{l}\text { IN / } \\
\text { IN }\end{array}$ & IN & IN & MX & 150 & 94.28 \\
\hline 150 & 700 & 75 & WS & 700 & $\mathrm{CA}$ & $\mathrm{CA}$ & CA & $\begin{array}{l}\text { MX / } \\
\text { US }\end{array}$ & $75 / 75$ & 90.94 \\
\hline 150 & $\begin{array}{l}\text { Country } \\
\text { limit* }\end{array}$ & $\begin{array}{l}\text { Country } \\
\text { limit* }\end{array}$ & WS & 700 & $\mathrm{CA}$ & MX & MX & $\begin{array}{l}\text { US / } \\
\text { MX }\end{array}$ & $145 / 5$ & 85.34 \\
\hline
\end{tabular}

* "No limit" cases use a fictitious infinite availability of all feedstocks in all locations; when a value is stated, that value is used for all locations (even though it might exceed the maximum in the given location); "Country limit" cases use the maximum availability/demand in each location as constraint.

Abbreviations

EtOH: ethanol, RM: raw material, PROD: product, AV: availability, DEM: demand, PRET: pretreatment, PROC: process, OF: objective function, CS: corn stover, WS: wheat straw. Countries (CA: Canada; CN: China; IN: India; MX: Mexico; US: USA) 
Table 5: Comparison of separation by distillation versus hybrid scheme for methanol-water mixture

\begin{tabular}{|l|l|l|l|l|}
\hline $\begin{array}{l}\text { Comparison } \\
\text { factors }\end{array}$ & \multicolumn{2}{|l|}{ Distillation } & Hybrid scheme & $\begin{array}{l}\text { Percentage } \\
\text { reduction }\end{array}$ \\
\hline Product purity & $90 \%$ & $99.5 \%$ & $99.5 \%$ & No change \\
\hline $\begin{array}{l}\text { Energy required } \\
\text { (KJ/h) }\end{array}$ & $2.98 \times 10^{6}$ & $6.7497 \times 10^{6}$ & $2.98 \times 10^{6}+105$ & $55 \%$ \\
\hline $\begin{array}{l}\text { Carbon footprint } \\
\text { (tons) }\end{array}$ & 0.94 & 0.52 & $44 \%$ \\
\hline
\end{tabular}


Table 6: Summary of improvements through process intensification

\begin{tabular}{|c|c|c|c|c|}
\hline \multirow[t]{2}{*}{ Comparison factors } & \multirow[t]{2}{*}{ Base case } & \multicolumn{2}{|c|}{$\begin{array}{l}\text { Intensified process } \\
\text { (alternatives) }\end{array}$} & \multirow[t]{2}{*}{ Remarks } \\
\hline & & 1 & 2 & \\
\hline Number of UOPs & 11 & 4 & 1 & \multirow{5}{*}{$\begin{array}{l}\text { Methyl acetate } \\
\text { production* }\end{array}$} \\
\hline $\begin{array}{l}\text { Energy Usage/kg } \\
\text { product }\end{array}$ & 21.88 & 19.12 & 2.225 & \\
\hline $\begin{array}{l}\text { Utility Cost } / \mathrm{kg} \\
\text { product }\end{array}$ & 0.10 & 0.08 & 0.01 & \\
\hline RM Cost/kg product & 0.88 & 0.87 & 0.87 & \\
\hline $\begin{array}{l}\text { Profit/kg product } \\
\text { (Fobj) }\end{array}$ & 2.06 & 2.09 & 2.16 & \\
\hline Number of UOPs & 5 & 3 & 1 & \multirow{5}{*}{$\begin{array}{l}\text { Dimethyl carbonate } \\
\text { production* }\end{array}$} \\
\hline $\begin{array}{l}\text { Energy Usage } / \mathrm{kg} \\
\text { product }\end{array}$ & 78.65 & 10.44 & 38.17 & \\
\hline $\begin{array}{l}\text { Utility Cost } / \mathrm{kg} \\
\text { product }\end{array}$ & 0.36 & 0.05 & 0.16 & \\
\hline RM Cost/kg product & 2.03 & 2.03 & 2.03 & \\
\hline $\begin{array}{l}\text { Profit/kg product } \\
\text { (Fobj) }\end{array}$ & 0.27 & 0.58 & 0.47 & \\
\hline Number of UOPs & 19 & 12 & & \multirow[t]{5}{*}{ Biodiesel production* } \\
\hline $\begin{array}{l}\text { Energy Usage } / \mathrm{kg} \\
\text { product }\end{array}$ & 119.16 & 73.10 & & \\
\hline $\begin{array}{l}\text { Utility Cost } / \mathrm{kg} \\
\text { product }\end{array}$ & 7.79 & 4.66 & & \\
\hline $\begin{array}{l}\text { Product/raw material } \\
\text { (ratio) }\end{array}$ & 0.94 & 0.94 & & \\
\hline $\begin{array}{l}\text { Total carbon footprint } \\
\text { (kg CO} 2 \text { equivalent) }\end{array}$ & 0.183 & 0.143 & & \\
\hline
\end{tabular}

* Detailed results producing the numbers in this table can be obtained from the authors 


\section{List of Figures}

Figure 1: Total world energy consumption from different energy sources (Data Source: The International Energy Outlook, 2016).

Figure 2: $\mathrm{CO}_{2}$ capture, sequestration and conversion steps.

Figure 3: $\mathrm{CO} 2$ emissions from use of fossil fuels (a) Use in all sectors including industrial, domestic and transport (b) Use only in industrial sector (Data Source: EIA 2016).

Figure 4: Fuel usage statistics in year 2015 (Data Source: Renewables information: Overview, IEA-2017).

Figure 5: Global capacity of Solar energy production in (a) Solar PV (b) CSP and (c) Solar water heating in the year 2015 and 2016 (Source: REN21, 2017).

Figure 6: Global cumulative installed wind capacity from 2001 to 2016 (Source: GWEC, 2016).

Figure 7: Sustainability challenges in geothermal energy production.

Figure 8: Boundaries in Process design (Hernandez, 2017).

Figure 9: Superstructure of alternative feedstocks, processing technologies and products for biomass-to-energy processes.

Figure 10: Biomass-to-ethanol superstructure (Bertran et al., 2017).

Figure 11: $\mathrm{CO} 2$ conversion network to produce methanol, dimethyl ether, dimethyl carbonate, ethylene glycol, propylene glycol

Figure 12: The number of power plants whose emissions can be reduced by the production of these products via carbon dioxide conversion processes. Note: this considers an average power plant as a 150MW coal-fired power plant.

Figure 13: The process flow diagram for the carbon dioxide capture and conversion to dimethyl carbonate via ethylene carbonate production. 


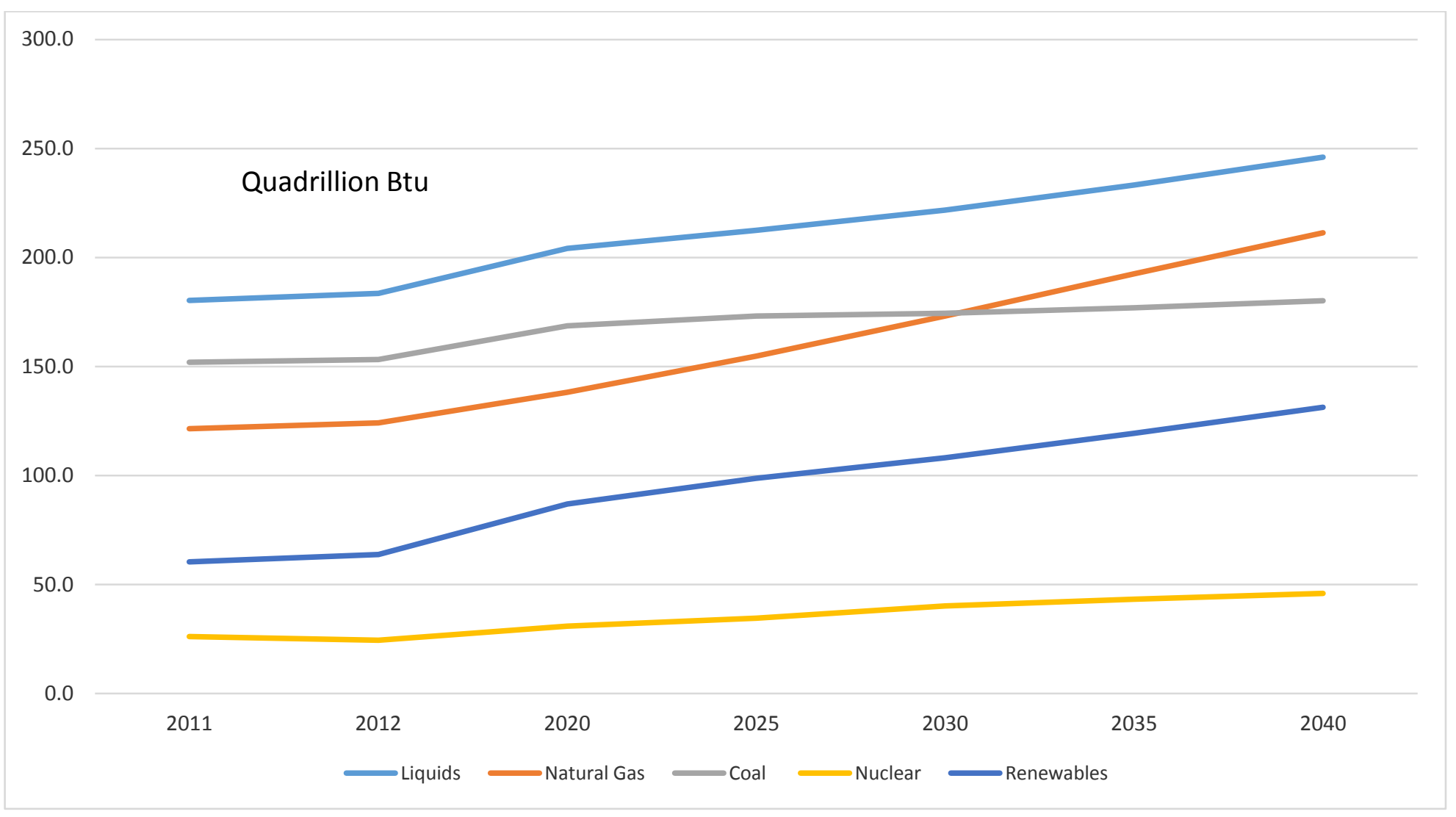

Figure 1: Total world energy consumption from different energy sources (Data Source: The International Energy Outlook, 2016). 


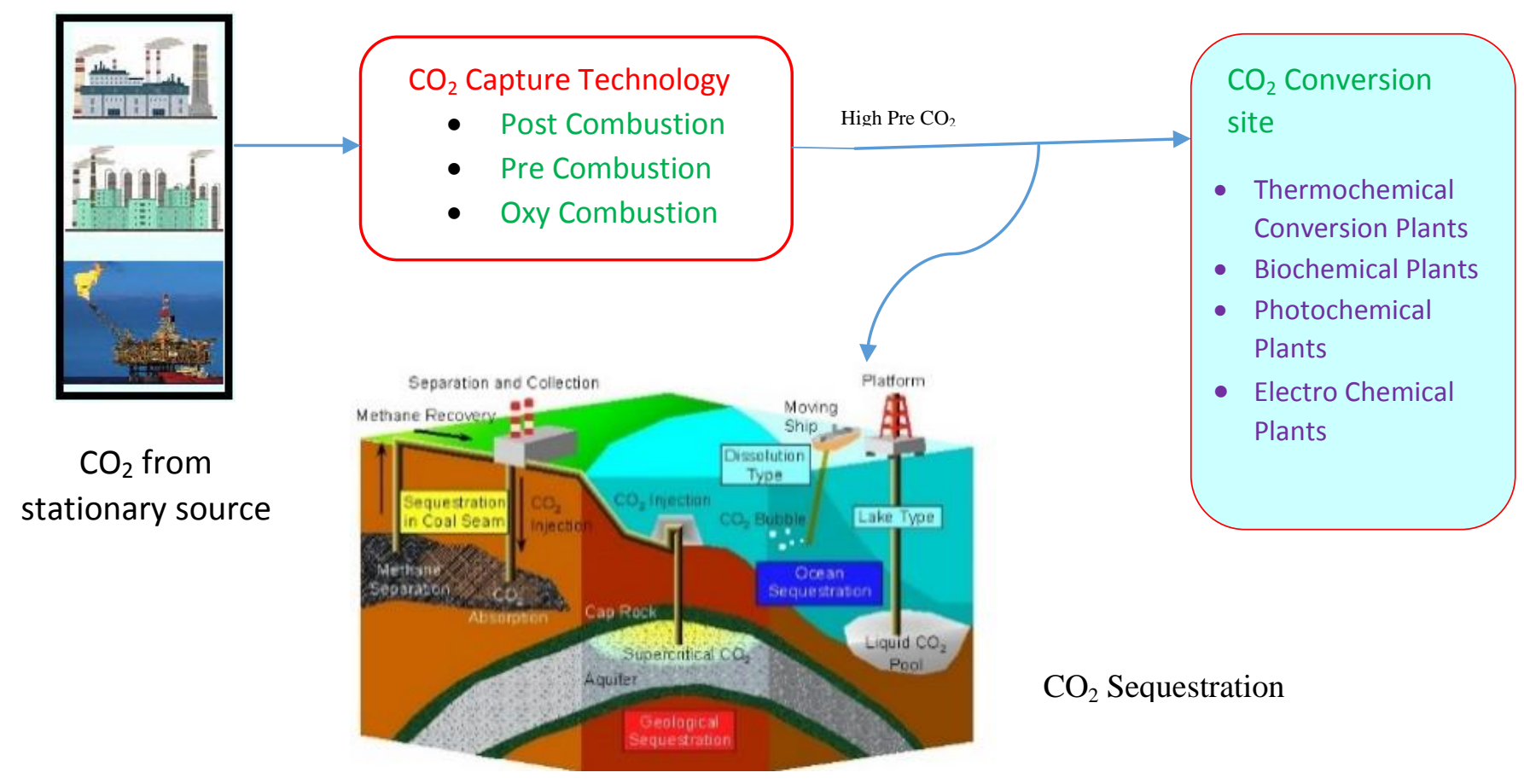

Figure 2: $\mathrm{CO}_{2}$ capture, sequestration and conversion steps. 


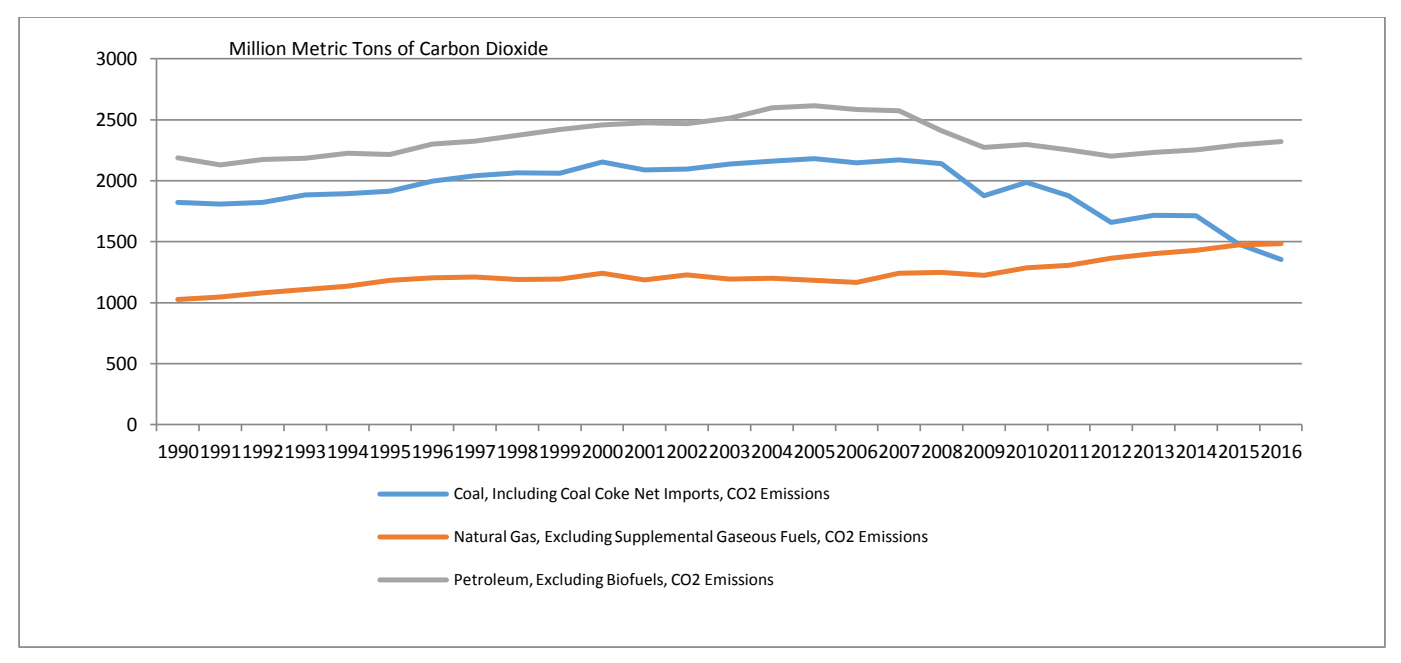

$3 a$

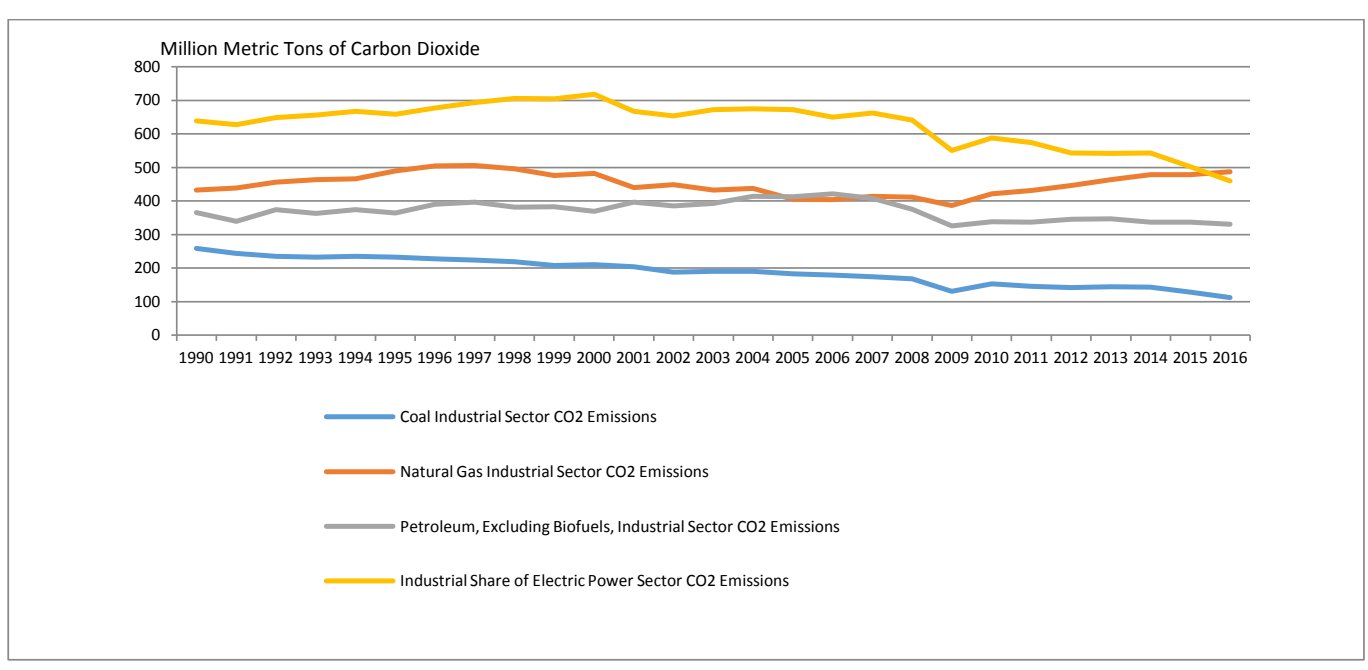

$3 b$

Figure 3: CO2 emissions from use of fossil fuels (a) Use in all sectors including industrial, domestic and transport (b) Use only in industrial sector (Data Source: EIA 2016). 


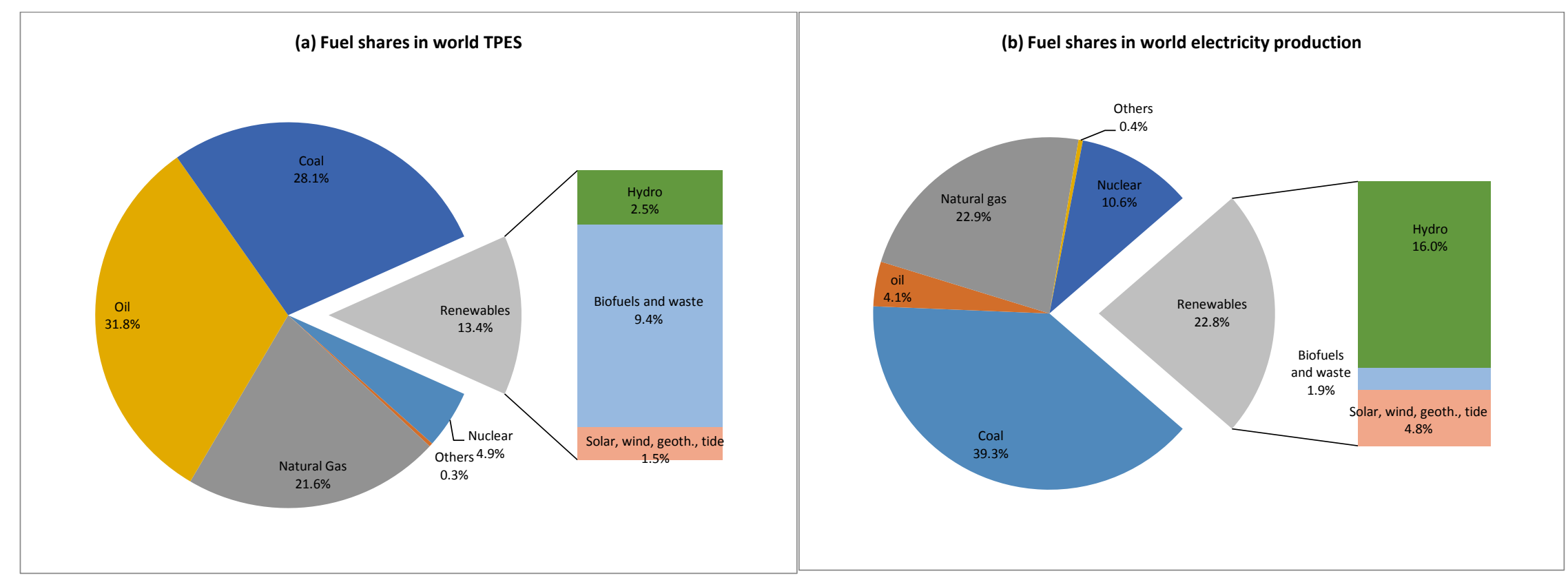

Figure 4: Fuel usage statistics in year 2015 (Data Source: Renewables information: Overview, IEA-2017). 

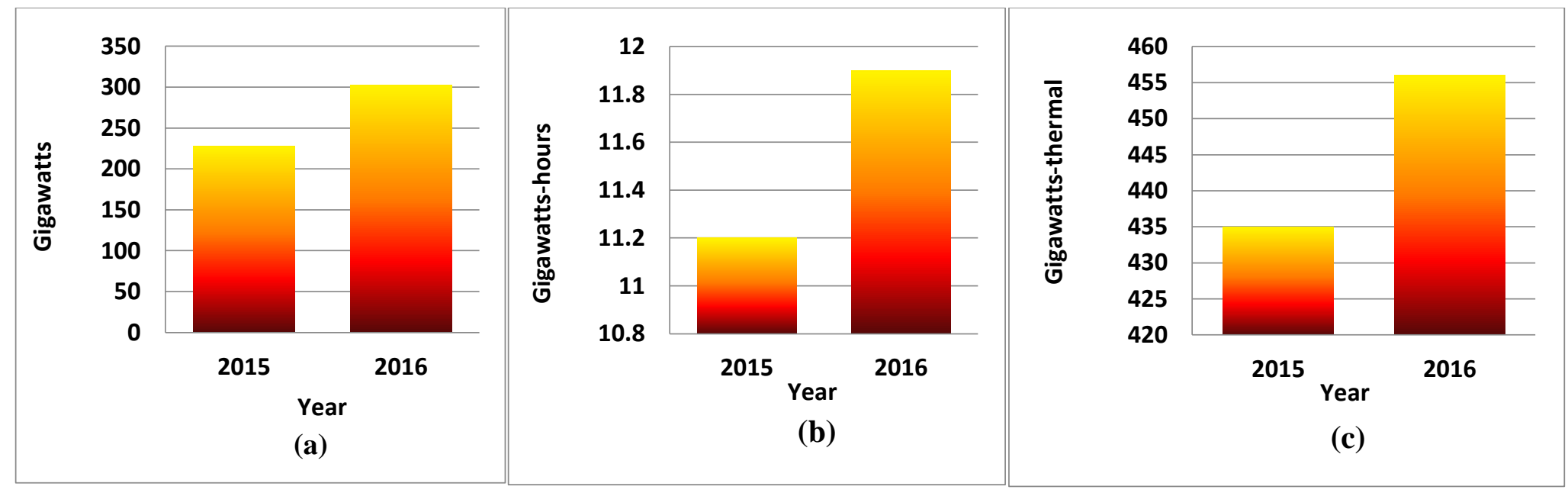

Figure 5: Global capacity of Solar energy production in (a) Solar PV (b) CSP and (c) Solar water heating in the year 2015 and 2016 (Source: REN21, 2017). 


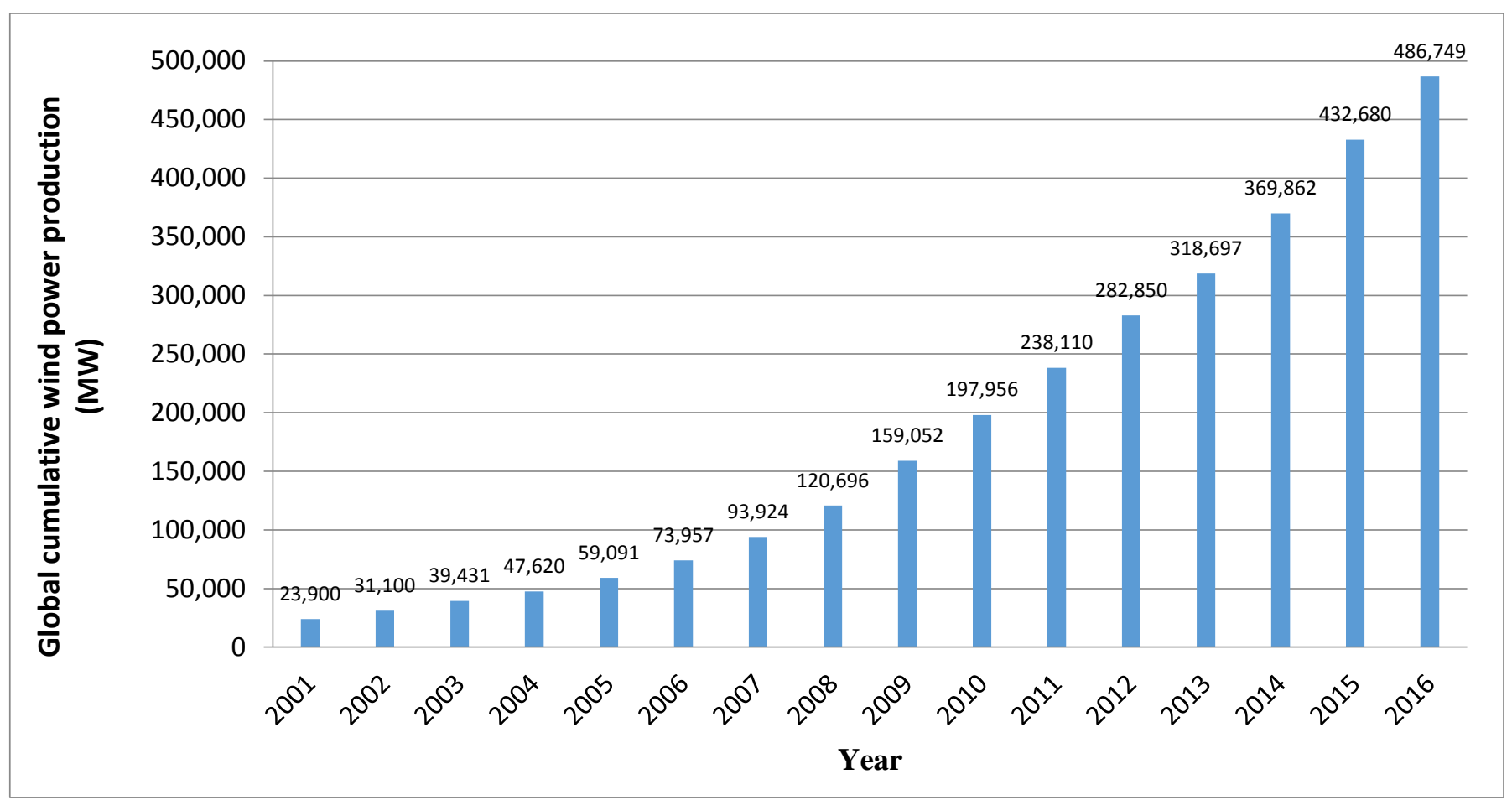

Figure 6: Global cumulative installed wind capacity from 2001 to 2016 (Source: GWEC, 2016). 


\section{Environmental Impacts}

Land: area required is high, lot of drilling activities, soil erosion, soil compaction, landslides.

Water: effects the water quality and water availability, interrupts the original hydrological cycle.

Air: release of dust into atmosphere, Release of not condensable gases such as $\mathrm{CO} 2, \mathrm{H} 2 \mathrm{~S}, \mathrm{CH} 4 \mathrm{Hg}$ from source fluid to atmosphere Biodiversity: Change in local ground temperatures, $\mathrm{pH}$ values, and water availability effects plants, animals, micro organisms and destroy the habitats

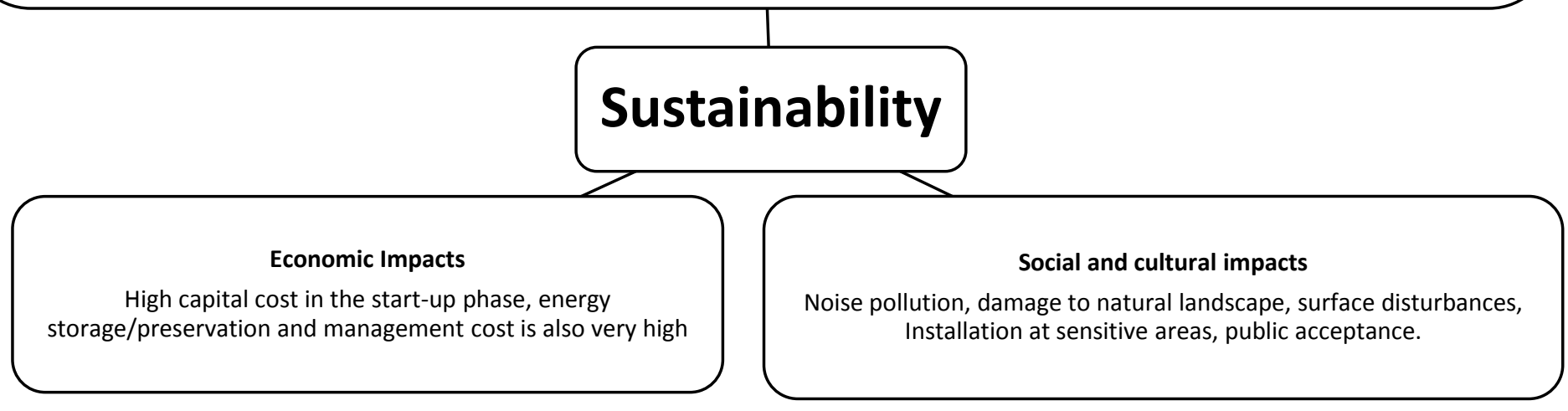

Figure 7: Sustainability challenges in geothermal energy production. 


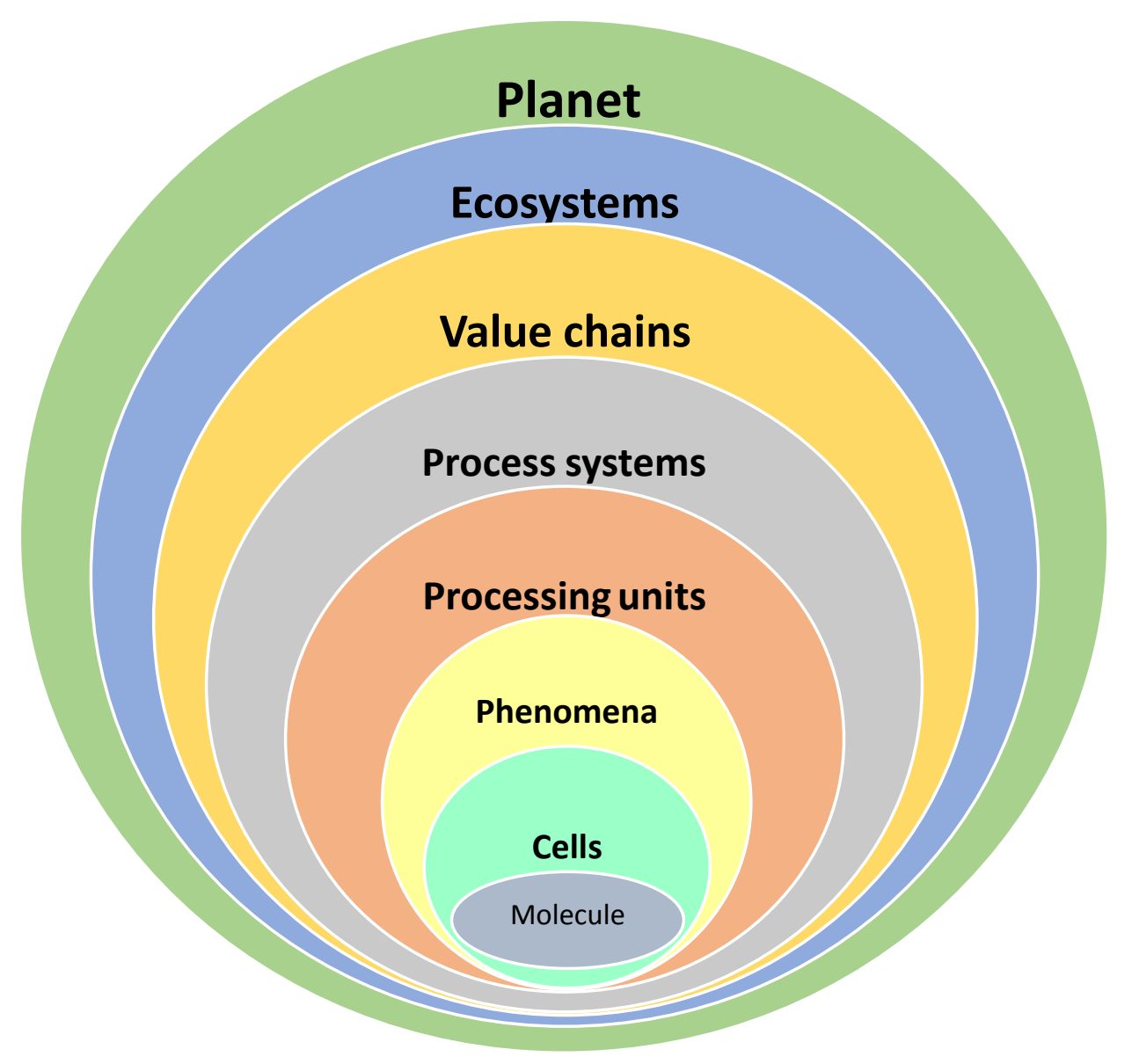

Figure 8: Boundaries in Process design (Hernandez, 2017). 


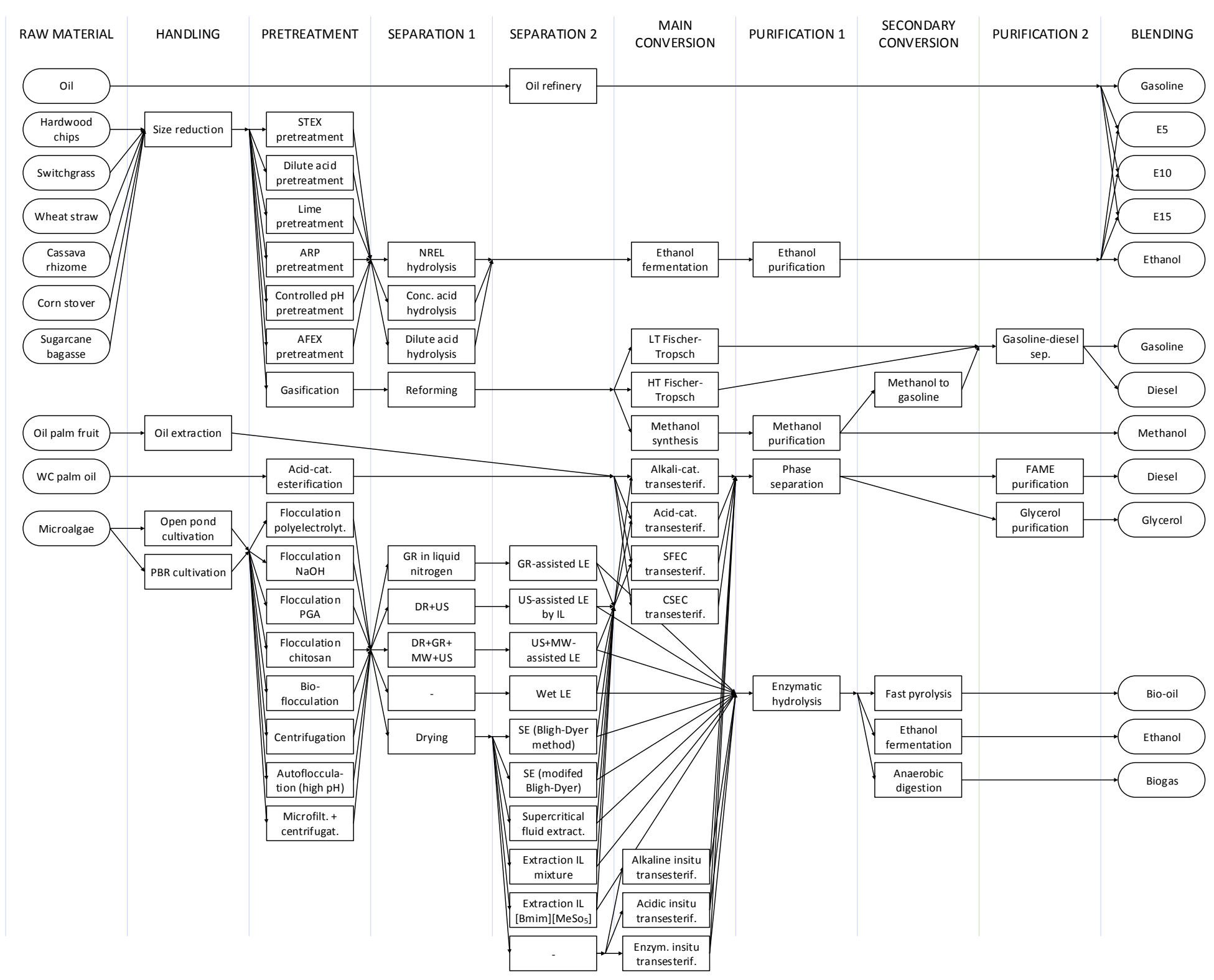

Figure 9: Superstructure of alternative feedstocks, processing technologies and products for biomass-to-energy processes. 


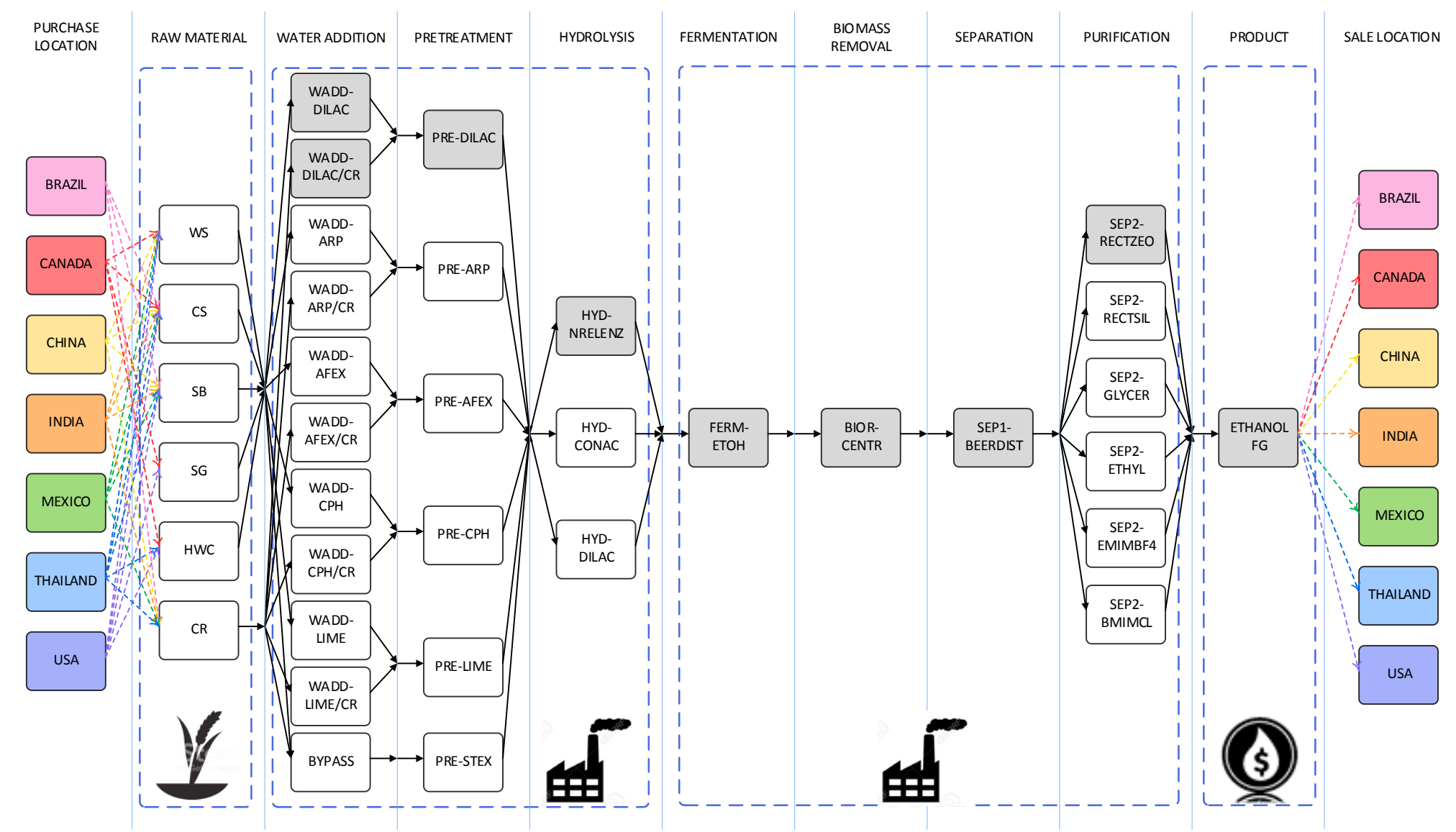

Figure 10: Biomass-to-ethanol superstructure with sections for allocation and fixed processing route highlighted.

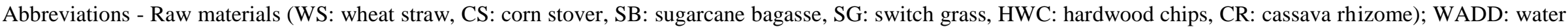

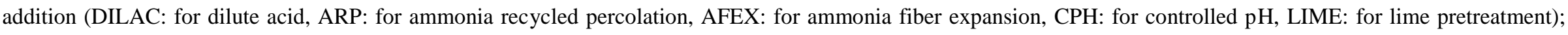

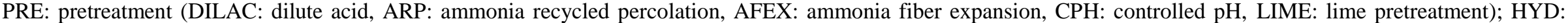

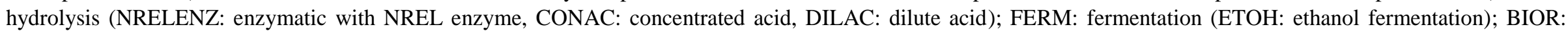

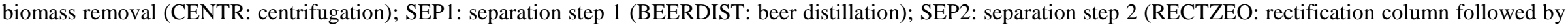

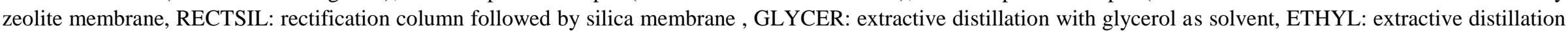

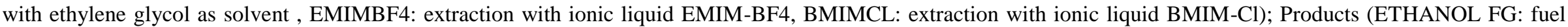
grade ethanol). 


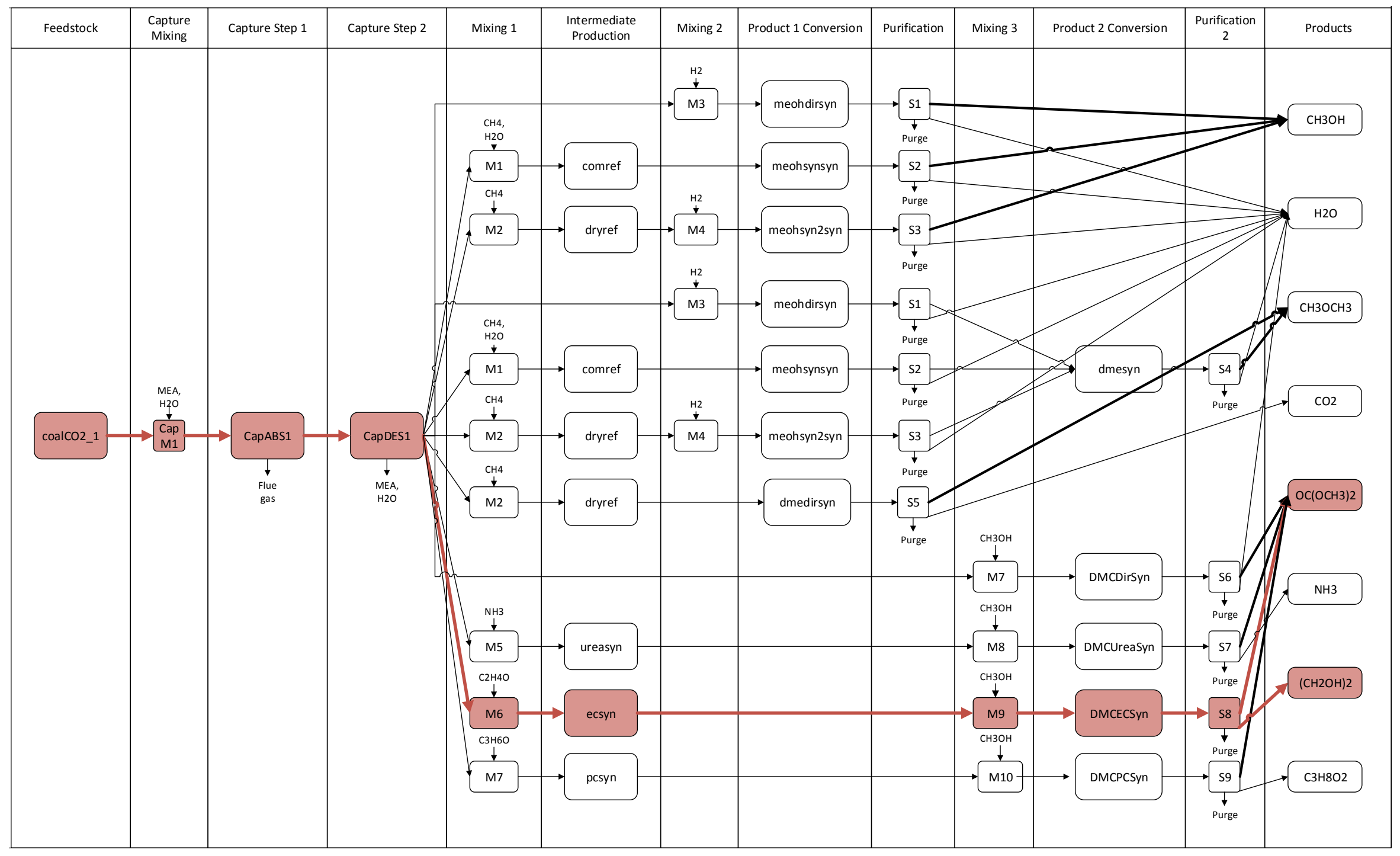

Figure 11: CO2 conversion network to produce methanol, dimethyl ether, dimethyl carbonate, ethylene glycol, propylene glycol 


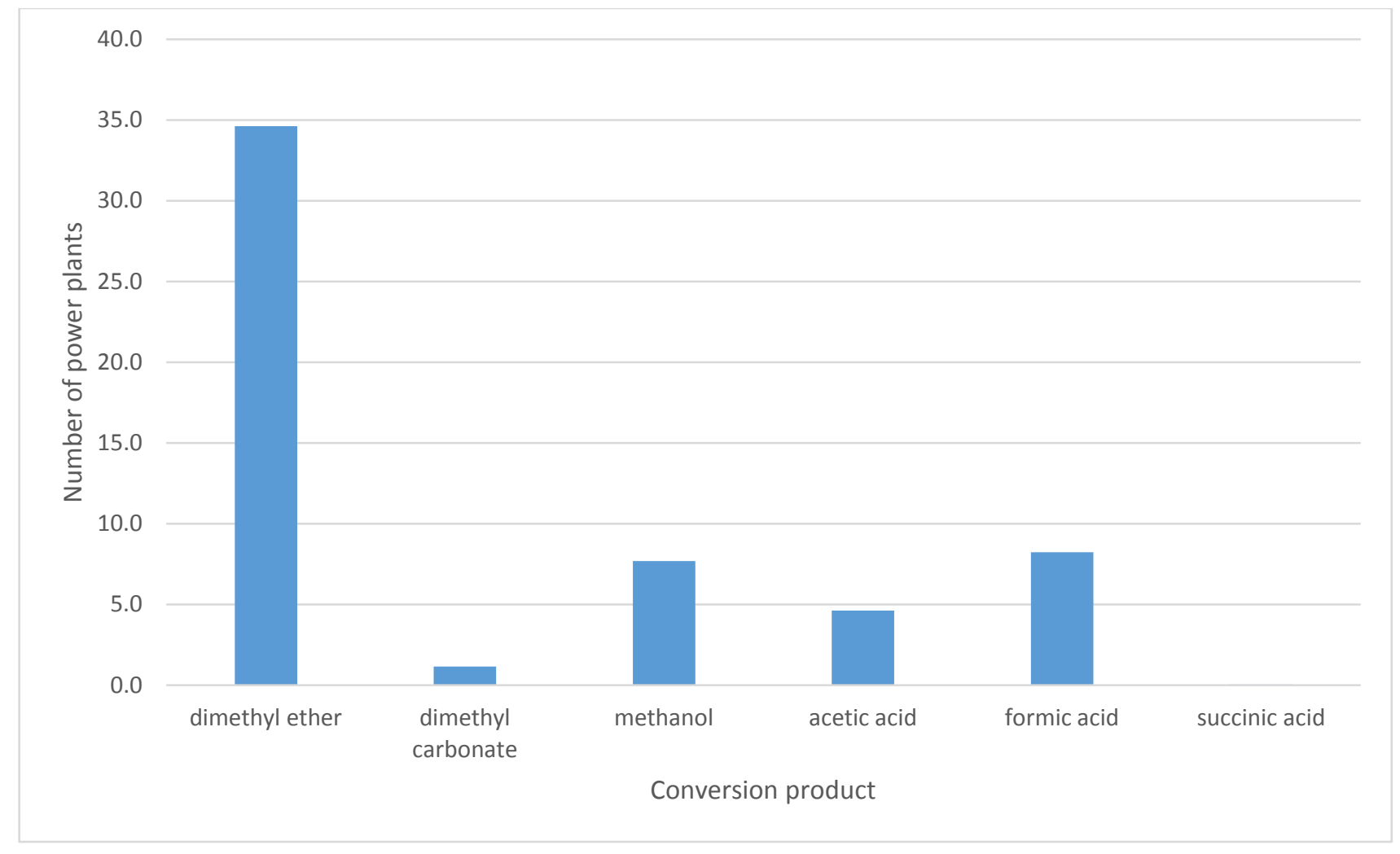

Figure 12: The number of power plants whose emissions can be reduced by the production of these products via carbon dioxide conversion processes. Note: this considers an average power plant as a $150 \mathrm{MW}$ coal-fired power plant. 


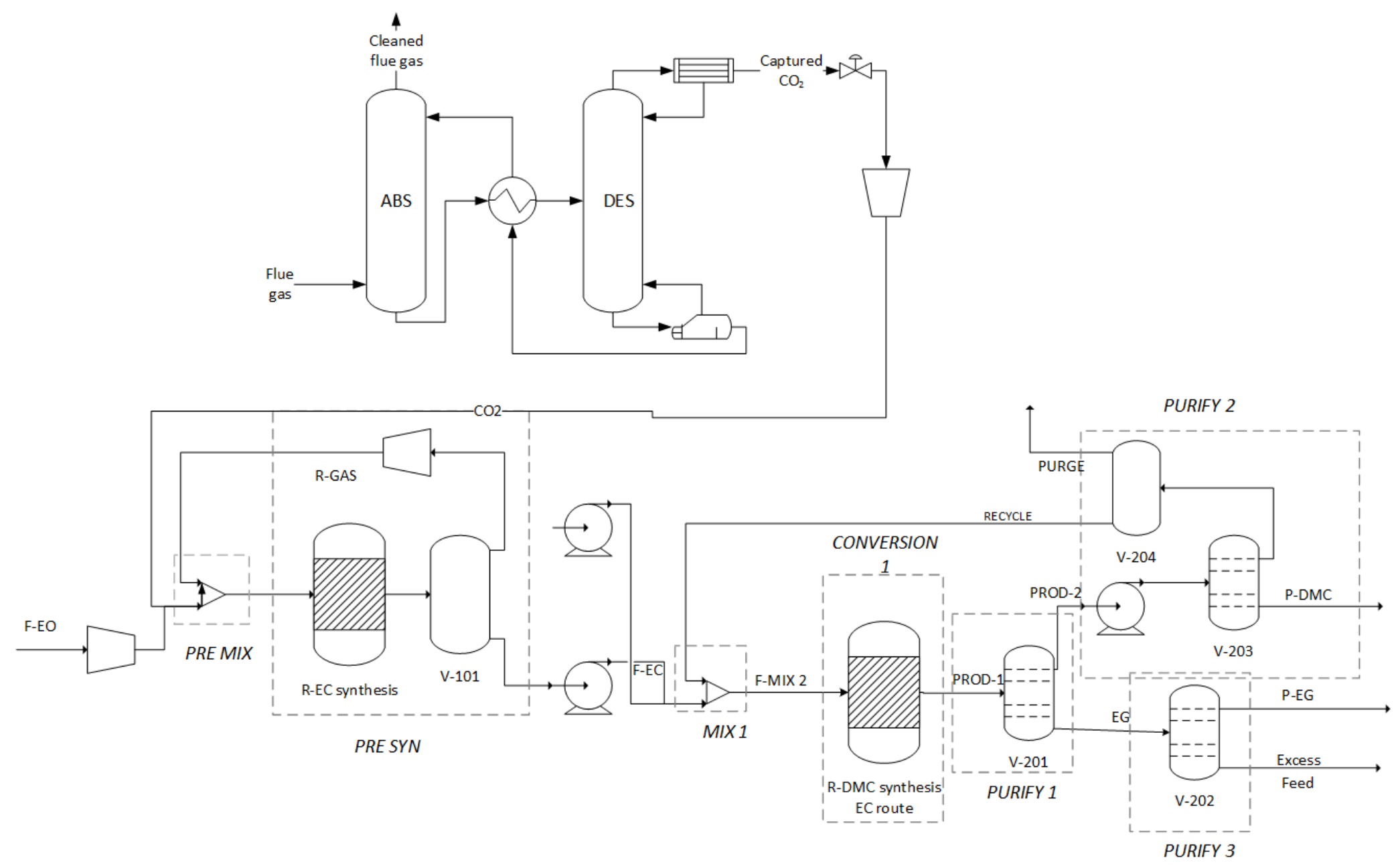

Figure 13: The process flow diagram for the carbon dioxide capture and conversion to dimethyl carbonate via ethylene carbonate production. 
